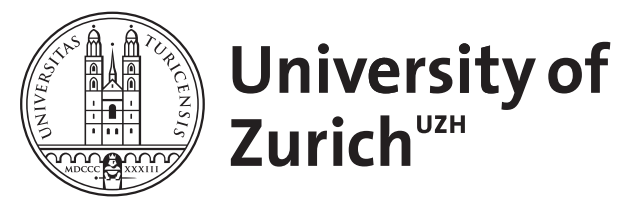

\title{
Drug transporters in the central nervous system
}

\author{
Stieger, Bruno ; Gao, Bo
}

\begin{abstract}
Drug targets in the central nervous system (CNS) are numerous and important for drug therapy, e.g., of epilepsy or pain. Drugs and other xenobiotics as well as nutrients cannot freely cross the blood-brain barrier or freely enter cells across plasma membranes and therefore require transport systems. This overview summarizes the current knowledge on the expression of drug transporters in barriers shielding the CNS from the systemic circulation and as such controlling the pharmacokinetics of drugs in the CNS. The main drug transporter families covered are SLCO, SCL22A, ABCB, and ABCC, as genes of these families code for numerous drug transporters. While knowledge on messenger RNA expression in humans, rats, and mice is remarkable, there is clearly a gap in knowledge on the subcellular expression of transporters in specific cells in the CNS and in the barriers shielding the CNS from the systemic circulation. Recent methodologic developments including synthesis of drugs and endogenous substances for imaging will in the future allow the investigation of the function and physiologic role of transporters in the CNS including difficult-to-access systems such as the choroid plexus.
\end{abstract}

DOI: https://doi.org/10.1007/s40262-015-0241-y

Posted at the Zurich Open Repository and Archive, University of Zurich ZORA URL: https://doi.org/10.5167/uzh-109614

Journal Article

Accepted Version

Originally published at:

Stieger, Bruno; Gao, Bo (2015). Drug transporters in the central nervous system. Clinical Pharmacokinetics, 54(3):225-242.

DOI: https://doi.org/10.1007/s40262-015-0241-y 


\section{Drug Transporters in the Central Nervous System}

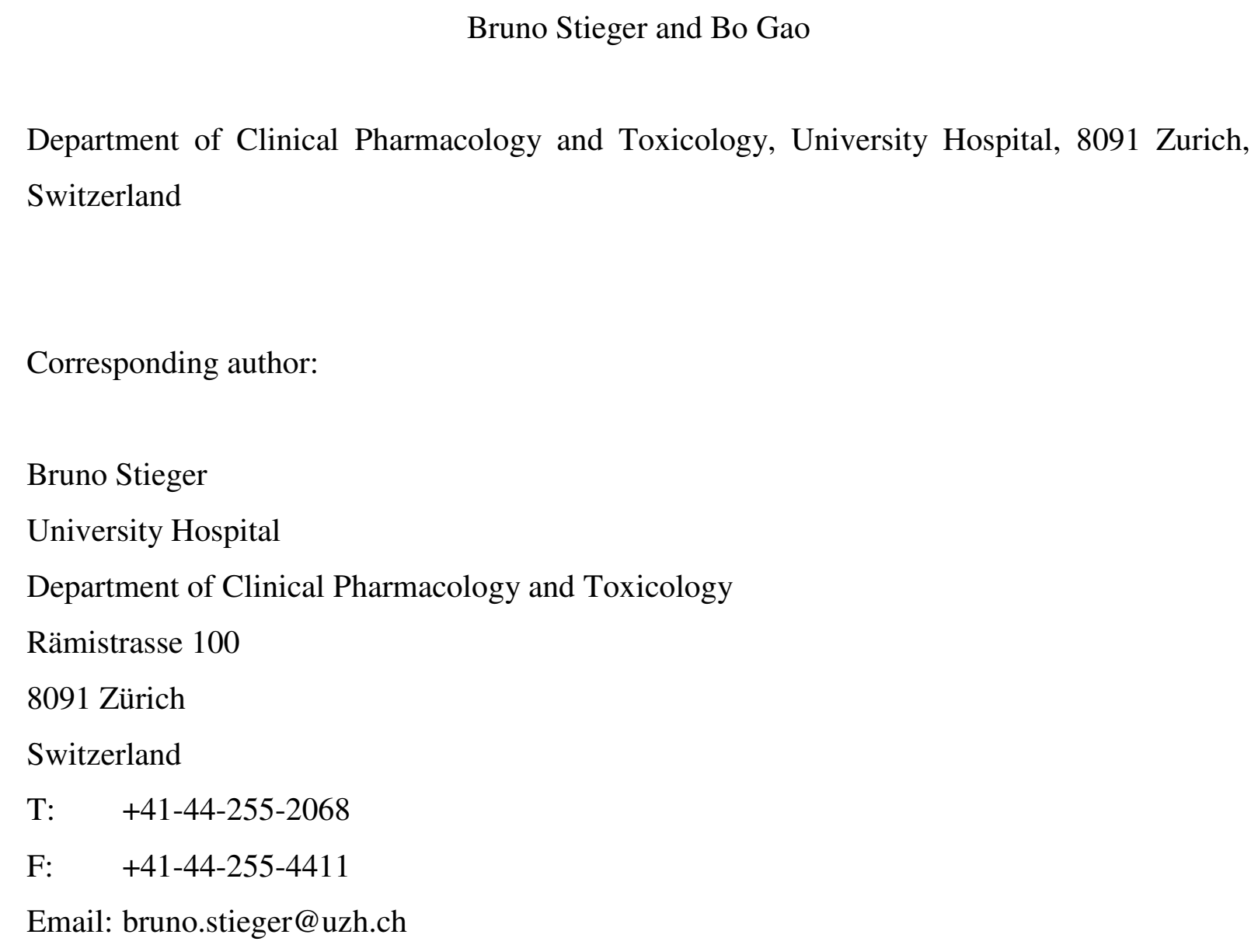

\section{Bruno Stieger and Bo Gao}

Department of Clinical Pharmacology and Toxicology, University Hospital, 8091 Zurich, Switzerland

Corresponding author:

Bruno Stieger

University Hospital

Department of Clinical Pharmacology and Toxicology

Rämistrasse 100

8091 Zürich

Switzerland

T: +41-44-255-2068

F: +41-44-255-4411

Email: bruno.stieger@uzh.ch 


\begin{abstract}
Drug targets in the central nervous system are numerous and important for drug therapy e.g. of pain, psychiatric disorders or epilepsy. Drugs and other xenobiotics as well as nutrients cannot freely cross the blood brain barrier or freely enter cells across plasma membranes and therefore require transport systems. This overview summarizes the current knowledge on the expression of drug transporters in barriers shielding the central nervous system form the systemic circulation and as such controlling the pharmacokinetics of drugs in the central nervous system. The main drug transporter families covered are SLCO, SCL22A, ABCB and $A B C C$, as genes of these families code for numerous drug transporters. While knowledge on mRNA expression in humans, rats and mice is remarkable, there is clearly a gap in knowledge on the subcellular expression of transporters in specific cells in the central nervous system and in the barriers shielding the central nervous system from the systemic circulation. Recent methodological developments including synthesis of drugs and endogenous substances as markers for imaging will in the future allow investigating the function and physiologic role of transporters in the central nervous systems including difficult to address systems like the choroid plexus in vivo.
\end{abstract}




\section{Introduction}

All organs in the mammalian body are connected via the blood circulatory system, which provides both the supply of vital nutrients and disposes waste products. In most instances, drugs also reach their target via the circulatory system regardless of the route of application. Organs are separated from the circulatory system by barriers, which may be leaky like e.g. in the liver or very tight like in the brain. The brain is separated from the blood by the bloodbrain barrier (BBB) and from the cerebrospinal fluid (CSF) by the choroid plexus (CP) [1, 2]. In addition, the brain also communicates with body extracellular fluids via the arachnoid epithelium [3], but this pathway contributes only minor to the exchange and is not subject of this overview. In order to cross barriers, which ultimately are always plasma membranes, transport systems are needed [4, 5]. Moreover, a tissue specific expression of transporters allows the body to accumulate substances, like e.g. drugs in an organ-specific manner [1, 4]. The tightness of the BBB severely limits the access of drugs to the brain and presents major challenge in the development of drugs with targets in the central nervous system (CNS) [6-8]. Therefore, the aim of this review is to summarize the current knowledge on the expression of drug transporters in the BBB and in the CP. As the retina is also part of the CNS, transporters in the blood-retina barrier (BRB) will also be addressed. Furthermore, we will also highlight the role of the transporters encountered by drugs and other substances once they have crossed the barriers surrounding the tissues of the CNS.

\section{Drug Transporters}

Solutes, like drugs need transporters to enter or exit cells. Generally, transporters mediating the cellular uptake of drugs belong to the superfamily of solute carriers (SLC). Efflux of drugs (or their metabolites) frequently occurs against a concentration gradient and is often mediated by members of the ATP-binding cassette (ABC) transporters. Numerous reviews have been published on both superfamilies of transporters. The SLC superfamily represents currently 52 families and 395 genes for individual transporters and has been covered recently in a special issue [9]. Human $\mathrm{ABC}$ transporter genes number to 48 members and are divided into seven families [10], but not all of them act as transporters [11]. It is beyond the scope and space of this review to describe the individual drug transporter families. This overview will focus on members of the SLCO and SLC22A gene families, which are well known to mediate in addition to endogenous substrates the transport of drugs. Among the $\mathrm{ABC}$ protein families, multidrug resistance protein 1 (MDR1) (ABCB1), ABCG2 (also called BCRP, ABCG2) and 
members of the $A B C C$ family are known to be important drug and drug metabolite transporters and will therefore be covered here.

Human drug transporters being members of the SLC superfamily and expressed in cerebral blood tissue barriers are listed together with rodent transporters in tables 1 to 5 . Rodent species are included as they are used as preclinical species in drug development and as they allow in vivo experiments not possible in humans for investigating their role in drug transport in the CNS. In these tables a selection of references (we apologize for omissions) had to be made and data on transport systems obtained from microperfusion experiments as well as from work with microcapillary endothelial cell lines are not included. Microperfusion experiments are most valuable for the elucidation of the in vivo situation for drug access to brain tissue but face the difficulty that many drug transporters have an overlapping substrate specificity [12-14]. Brain capillary endothelial cell lines and very likely also other established cell lines display altered transporter expression levels in comparison to their in vivo counterparts $[15,16]$. It should be realized that there are often conflicting data in the literature. Good examples are the members of the $A B C C$ family, about which conflicting data on the expression in the BBB exist up to date [17]. This may relate to the fact that for animals, within a species, different strains show different transporter expression. E.g. in mice, mouse multidrug resistance-associated protein 2 (MRP2) could be detected in the BBB of C57BL/6, Swiss and SvJ, but not FVB mice, while liver and kidney showed positive staining in all strains [18]. Similarly, the expression levels of the mouse monocarboxylate transporter MCT1 in the BBB of C57BL/6J mice were significantly lower than in ddY or FVB mice, while the expression of mBCRP was significantly higher in C57BL/6J mice compared to ddY or FVB mice when analyzed by quantitative targeted proteomics [19]. In human studies, tissue procurement and storage prior to analysis as well as sampling biases will considerably contribute to variable data sets. For protein expression, preference to data obtained from proteomic approaches where available was given over data obtained by Western blotting. Transporter expression in blood neural tissue barriers has additionally been covered in many overviews [17, 20-31].

\section{Blood-Brain-Barrier}

In order to provide a stable environment for the CNS, the BBB needs to be able to tightly control the access of substances to the brain. To this end, the endothelial cells lining the walls of the brain capillaries form together with tight junctions an impervious barrier [2]. Brain 
access of substances (e.g. nutrients like e.g. D-glucose) is consequently controlled by transport proteins specifically expressed in the luminal and/or abluminal membrane of brain capillary endothelial cells [2]. Nutrients are transported into the brain by influx systems such as for example amino acids by members of the SLC1A family [32]. Many of these transporters are equilibrative, i.e. they cannot work against concentration gradients. Extrusion of substances from brain occurs at the luminal membrane and is mediated by $\mathrm{ABC}$ transporters like MDR1 [33]. ABC transporters utilize energy provided from ATP hydrolysis and can therefore establish steep concentration gradients. While SLC transporters expressed in plasma membranes are often uptake transporters, some members act as exchanger of solutes and consequently mediate may mediate efflux of a substrate in exchange for uptake of another substance [9]. Consequently, the direction of solute transport by such transporters has to be determined experimentally, ideally in situ in the organ of interest.

Drug transporters being members of the SLC superfamily and expressed in BBB are listed in table 1. Specifically, the protein expression of several SLC superfamily members involved in drug transport (4 organic anion transporting polypeptides (OATPs) (SLCO), two organic cation transporters (OCTs) (SLC22A), one organic cation transporter novel type (OCTN) (SLC22A), one concentrative nucleoside transporter (CNT) (SLC28A) and two equilibrative nucleoside transporters (ENTs) (SLC29A)) has been reported for human BBB (Table 1). SLC family members are either facilitating uptake transporters secondary active transporters capable of working against concentration gradients [9]. Consequently, drug transporters expressed in the luminal membrane of the $\mathrm{BBB}$ are potential entry sites for drugs or toxins into the BBB. In the case of non-polar expression (i.e. in the luminal and in the abluminal membrane of the $\mathrm{BBB}$, these transporters may allow their substrates to cross the endothelial cells of the BBB and the entry into the brain. The number of substrates including drugs for SLC family members known today is overwhelming and listing them is beyond the scope of this overview. Lists of substrates can be found in the following (as well as many additional) reviews: for OATPs [13, 34, 35]; for OATs [36-38]; for OCTs [37, 39]; for CNTs [40, 41]; for ENTs [41, 42] and for MATEs [43, 44].

Several examples demonstrate indirectly and directly the pharmacologic and toxicologic role of SLC transporters in the BBB of humans. Drugs used for treatment of pain often need to enter the CNS [45]. Triptans are drugs used to treat migraine. It was recently demonstrated that several triptans are substrates of OATP1A2 expressed in BBB (table 1) [46]. Hence, it is 
reasonable that hydrophilic triptans may use OATP1A2 to cross the BBB. The relative transport rate of OATP1A2-mediated transport decreases from triptans with tertiary to triptans with primary amines in heterologous expression systems [46]. While transport of drugs across the $\mathrm{BBB}$ is considered to be beneficial this is not the case for toxins. This is exemplified by an incidence in Brazil, where 126 patients of a hemodialysis unit suffered from a microcystin intoxication and 60 patients subsequently died [47]. The patients developed acute neurotoxicity and subacute hepatotoxicity. Expressing OATP1A2 in Xenopus laevis oocytes allowed demonstrating that this transporter mediates uptake of microcystin [48]. Moreover, OATP1A2 expression was required for microcystin to exert its toxic effects on oocytes. Lately, it was reported that OATP1A2 is expressed in neurons in human brain [49]. This finding adds an additional piece to the mechanistic understanding of microcystin toxicity: Microcystin inhibits protein phosphatases at nanomolar concentrations [50]. Hence the expression of OATP1A2 in neurons may allow microcystin, once it has crossed the BBB, the entry into neurons followed by impairment of neuronal functions. Looking at an endogenous compound, thyroid hormones are instrumental for the development of brain and in adult life for metabolic adaptation [51]. OATP1C1, which is expressed at the BBB (table 1) [52] is a high-affinity thyroid hormone transporter [53] and consequently allows the entry of thyroid hormones into brain. These examples clearly demonstrate that expression of transport proteins in the $\mathrm{BBB}$ in addition to endogenous substances allows the entry of xenobiotics into the brain. Hence, understanding the molecular properties of transporters working in the BBB will contribute to a better understanding of the penetration of drugs across the BBB to reach pharmacodynamics targets in the brain. Therefore, the relevance of the BBB as a selective guard of the brain is not only recognized by physiologists and pharmacologists but has also initiated large efforts for developing tools to study the impact of BBB early in drug development $[8,54]$.

$\mathrm{ABC}$ transporters are mostly cellular efflux transporters and either act as cellular defense systems for substances or export them from the cytoplasm [9]. They are often located in strategic organ boundaries including $\mathrm{BBB}$, where they are most important for controlling access to body sanctuaries [55]. The importance of ABC transporters is further emphasized by the observation that more than 20 (out of 48) human $\mathrm{ABC}$ transporters are important in various acquired and inherited human diseases [56]. Drug transporters being members of the $\mathrm{ABC}$ superfamily and expressed in human $\mathrm{BBB}$ are listed in table 2 . The protein expression of several $\mathrm{ABC}$ transporter superfamily members involved in drug transport (one MDR) 
$(A B C B)$, four MRPs $(A B C C)$, and one ABCG $(A B C G)$ has been reported for human $\mathrm{BBB}$

(Table 2). With respect to drug transport, members of the $A B C B, A B C C$ and $A B C G$ family are capable of transporting numerous drugs. List of substrates including drugs for drug transporting $\mathrm{ABC}$ family members can be found e.g. in the following reviews: [27, 57-67].

The brain protective role of $\mathrm{ABC}$ transporters at the $\mathrm{BBB}$ is best illustrated with the clinical studies aimed at inhibiting MDR1 in drug treatment of cancer. For example, in a phase I trial coadministration of etoposide and cyclosporine lead to more severe nausea in some patients receiving both drugs [68]. In another phase I study where etoposide and the second generation MDR1 inhibitor PSC 833 were combined to treat cancer patients, severe ataxia was observed as dose-limiting toxicity of PSC833 [69]. In this case, the MDR1 inhibitor allowed etoposide to cross the BBB inducing neurotoxicity. The same toxicity was later observed in a phase III trial [70]. Similarly, a high-dose oral tamoxifen phase I trial in combination with verapamil revealed dose-limiting neurologic side effects [71]. Taken together, these few examples in humans demonstrate the importance of luminal $\mathrm{ABC}$-transporters in $\mathrm{BBB}$ as gate keepers preventing or lowering the exposure of the brain to potentially neurotoxic agents. In principle, given access of a substrate into $\mathrm{BBB}$, abluminal $\mathrm{ABC}$-transporters should enhance the exposure of the brain to their substrates. To the best of our knowledge we found no such examples in the literature.

\section{Choroid Plexus}

The $\mathrm{CP}$ is located in the lateral third and forth brain ventricles and produces the cerebrospinal fluid. It is a highly vascularized organ containing in the stroma loose connective tissue and a fenestrated endothelium. A tight monolayer of $\mathrm{CP}$ epithelial cells connected by tight junctions near the apical surface forms the blood cerebrospinal fluid barrier (BCSFB) [72-74]. In addition to its central role in the production of cerebrospinal fluid (CSF), it also removes organic anions as well as drugs and drug metabolites from the CSF, making the $\mathrm{CP}$ an important detoxifying system for the CSF [72, 73].

The protein expression of several SLC superfamily members involved in drug transport has so far been reported for CP. In humans (two OATPs and two OATs are identified in CP (Table 3 ) and one member of the $A B C B$ and two members of the $A B C C$ family have been demonstrated at the protein level (table 4). Inferring from rodent tissues, the two MRPs likely are expressed in the basolateral membrane of human $\mathrm{CP}$ epithelial cells and consequently 
mediate export of substances form the CSF back into blood after their uptake across the apical membrane. The individual role of these transporters in drug transport cannot be directly assessed in humans despite the fact that e.g. analgetics and anticancer drugs are administered to patients via an intrathecal route. Clearance of such drugs from the CSF is obvious, but in addition to the $\mathrm{CP}$, the villi of the arachnoids may also be involved in elimination of substances from the CSF. Drug transporter expression in arachnoid villi is still a largely uncharted area. In addition, the hydrodynamics of the cerebrospinal fluid, which may contribute to drug elimination from this body compartment is rather controversial [74, 75].

\section{Blood Ocular Barrier}

The retina is an organ rich in neurons. The retina is exposed on the anterior side to the vitreous humor and at the posterior side to the choroid. In the retina, there exist two BRB, namely the inner BRB formed by retinal capillary endothelial cells and the outer BRB formed by the retinal pigmented epithelial cells $[21,76]$. These two barriers prevent uncontrolled entry of blood constituents into the eye. Consequently, either one or both of these barriers needs to be overcome by drugs, which are systemically administered for treatment of retinal diseases.

The protein expression of several SLC superfamily members involved in drug transport (three OATPs, one OATs and one member of the ABCB and $\mathrm{ABCC}$ families each has so far been reported for human BRB (Table 5). Direct information on the role of transporters in drug permeation through the BRB in humans is missing, but it should be noted that systemically administered antibiotics reach the vitreous humor, e.g. ciprofloxacin [77] or daptomycin [78]. Ciprofloxacin is known to interact with OATPs [79]. Also, prostaglandins are used as first line treatment of glaucoma [80] and are substrates of OATPs [81, 82]. While these examples do not prove that transport systems are involved in the ocular disposition of drugs, they are nevertheless strongly indicative, as in particular daptomycin is rather membrane impermeable.

\section{Animal models for investigating the role of drug transporters in the central nervous} system

Animal models are a potent means to investigate the role of transporters in the CNS. Such models yield most valuable information on the function of drug transporters both at blood tissue barriers in the CNS as well as on their physiologic role in the CNS. For example, more than 50 years ago it was demonstrated in a goat model that phenolsulfonphthalein (also called 
phenol red), which at physiologic $\mathrm{pH}$ is a dianionic compound and the anionic angiographic contrast agent diodrast are actively transported out from the CSF into blood [83]. The understanding and consequently appreciation of the role of transporters in the BBB changed with the seminal work by Schinkel and coworkers who demonstrated that in mice with an inactivated $M d r l a$ gene the issue concentration in brain was 87-fold increased in comparison to controls and 22.4 fold for vinblastine [84]. In addition, the same team found no negative effect on the physiology of mice when both $M d r 1$ genes were inactivated, indicating that in this species mMDR1 (table 2) plays no vital role [85]. In contrast, mice with a disrupted Abcg2 gene gave conflicting results on the role of mABCG2 in the BBB (table 2) [86]. However, if studies were performed in mice, which in addition to Abcg2 had also disrupted Mdrl genes, it became clear that for some drugs Abcg2 contributes to preventing drugs from crossing the BBB. This example nicely illustrates the complexity of in vivo studies with drugs sharing multiple transporters. Also the role of mOATPs (table 1) in penetrating the BBB became evident in mice with a knockout of Slcola4 [87] as well as with the Slcola/lb locus, as in such animals statins showed a considerably lower entry into brain [88].

Genetically modified mice can also be used to study the efflux of drug metabolites produced in brain. Oseltamivir is an ethylester prodrug for Ro 64-0802. The latter is an inhibitor of neuraminidase and as such used in the prophylaxis and treatment of influenza virus infections [89]. This drug is associated with adverse psychiatric effects [90]. Oseltamivir is activated by carboxylesterase 1 [89], which is among other organs also expressed in brain [91]. Studies with $A b c b 1$ knockout mice showed that mMDR1 isoforms limit brain access of oseltamivir across the BBB [92]. Mircoinjection of RO 64-0802 into the brain of rats deficient either for Abcc4 or SLC22a8 demonstrated that both, mMRP4 (table 2) and mOAT3 (table 1) are involved in the elimination of RO 64-0802 from the brain across the BBB [93].

The opposite localization with respect to the lumen of blood vessels in the BBB (table 4) and in the $\mathrm{CP}$ (table 5) of MDR1 and ABCG2 leads to differential effects on the brain entry of drugs across the $\mathrm{BBB}$ and into the CSF. Mice with an $A b c b 1$ or $A b c g 2$ knockout show an increased accumulation of topotecan in the brain parenchyma, while its penetration into the CSF is reduced [94]. In double knockout animals, these effects were additive for both barriers. In mice with and inactivated $S c l 22 a 8$ gene, accumulation of fluorescein into the isolated CP was greatly reduced in comparison to wild type animals [95]. Hence, knock-out 
mice provide a most valuable tool to investigate the impact of transporters not only in the BBB but also in CP [96].

OATP1C1 was identified as a high affinity thyroxine transporter [53], which is expressed at the $\mathrm{BBB}$ (table 1) and in the $\mathrm{CP}$ (table 5). Mice having an inactivated Oatp1cl gene showed a significantly reduced brain content of $\mathrm{T} 4$ and $\mathrm{T} 3$ with no change in the plasma concentration of these two thyroid hormones [97], clearly demonstrating the important role of this transporter for thyroid hormone supply to the brain. In the same knockout mice strain, uptake of sulforhodamine 101 into astrocytes of the hypocampus is severely impaired [98].

\section{Outlook}

Ample evidence accumulated in recent years indicates the importance of transporters expressed in $\mathrm{BBB}, \mathrm{CP}$ and $\mathrm{BRB}$ for mediating the passage of drugs as well as nutrients and metabolites. Great progress has also been made, in particular in model animals, in the identification and quantification of transport proteins in these barriers. The depth of knowledge however varies considerably between the different barriers and the different species as the availability of $\mathrm{CP}$ and even more so of the BRB is very limited, in particular from humans. Hence, alternate tools such as good antibodies are urgently needed for defining the transporter inventory in these barriers. Importantly, antibodies have a major advantage in that they are key to define the subcellular expression of transporters in barriers. As movement of substances across barriers into and out from the CNS is often unidirectional and in some instance may occur against concentration gradients, exact knowledge on the subcellular expression of transporters together with and understanding in their transport mechanism is key for understand the contribution of individual transporters to the passage or blockage of compounds across these barriers. Progress in this area may in future come from a systems biology approach aimed at generating antibodies against a larger number of human proteins, like for example the Human Protein Atlas project [99]. In addition, advances in the field of targeted proteomics should certainly help to increase the knowledge needed for developing pharmacokinetic models for the uptake of drugs into the brain and for the export of drug metabolites from the brain [16]. In addition, for developing novel kinetic models for brain uptake and export, the contribution of drug metabolism, e.g. in BBB has to be taken into account [23]. 
Imaging methods and in particular positron emission tomography (PET) have made rapid and large progress in recent years such that PET becomes a feasible tool for studying the function of transporters in vivo [100]. First studies with healthy subjects [101] and with patients suffering from epilepsy $[102,103]$ have clearly provided data demonstrating that imaging of in vivo function of transporters not only in animal models but also in humans will soon become a very valuable tool for understanding drug transport across barriers shielding the brain. It is important to note that transporter function in vivo cannot only be monitored by PET, but also by single-photon emission-coupled tomography [104]. The development of novel imaging probes should in the future certainly help the development of novel drugs with targets in the CNS, as their passage through the barriers can be followed in vivo. This methodology, together with stringent quality control of the label [105], will certainly also help to address issues of transporter based drug-drug interactions at the $\mathrm{BBB}$, where clearly more information for clinics is needed [20, 106, 107]. 


\section{Acknowledgements}

Bruno Stieger is supported by Grant \# 310030_144195 from the Swiss National Science

Foundation and by the National Center of Competence in Research (NCCR) TransCure (University of Berne, Switzerland). 


\section{References}

1. Kusuhara H, Sugiyama Y. Role of transporters in the tissue-selective distribution and elimination of drugs: transporters in the liver, small intestine, brain and kidney. J Control Release. 2002 Jan 17;78(1-3):43-54.

2. Abbott NJ, Patabendige AA, Dolman DE, Yusof SR, Begley DJ. Structure and function of the blood-brain barrier. Neurobiology of disease. 2010 Jan;37(1):13-25.

3. Yasuda K, Cline C, Vogel P, Onciu M, Fatima S, Sorrentino BP, et al. Drug transporters on arachnoid barrier cells contribute to the blood-cerebrospinal fluid barrier. Drug Metab Dispos. 2013 Apr;41(4):923-31.

4. Dobson PD, Kell DB. Carrier-mediated cellular uptake of pharmaceutical drugs: an exception or the rule? Nat Rev Drug Discov. 2008 Mar;7(3):205-20.

5. Kell DB, Dobson PD, Oliver SG. Pharmaceutical drug transport: the issues and the implications that it is essentially carrier-mediated only. Drug discovery today. 2011 Aug;16(15-16):704-14.

6. Cecchelli R, Berezowski V, Lundquist S, Culot M, Renftel M, Dehouck MP, et al. Modelling of the blood-brain barrier in drug discovery and development. Nat Rev Drug Discov. 2007 Aug;6(8):650-61.

7. Jeffrey P, Summerfield SG. Challenges for blood-brain barrier (BBB) screening. Xenobiotica. 2007 Oct-Nov;37(10-11):1135-51.

8. Jeffrey P, Summerfield S. Assessment of the blood-brain barrier in CNS drug discovery. Neurobiology of disease. 2010 Jan;37(1):33-7.

9. Hediger MA, Clemencon B, Burrier RE, Bruford EA. The ABCs of membrane transporters in health and disease (SLC series): introduction. Mol Aspects Med. 2013 Apr-Jun;34(2-3):95107.

10. Moitra K, Dean M. Evolution of $A B C$ transporters by gene duplication and their role in human disease. Biol Chem. 2011 Jan;392(1-2):29-37.

11. Stieger B, Higgins CF. Twenty years of ATP-binding cassette (ABC) transporters. Pflugers Arch. 2007 Feb;453(5):543.

12. Konig J, Muller F, Fromm MF. Transporters and drug-drug interactions: important determinants of drug disposition and effects. Pharmacol Rev. 2013 Jul;65(3):944-66.

13. Hagenbuch B, Stieger B. The SLCO (former SLC21) superfamily of transporters. Mol Aspects Med. 2013 Apr-Jun;34(2-3):396-412. 
14. Wong K, Ma J, Rothnie A, Biggin PC, Kerr ID. Towards understanding promiscuity in multidrug efflux pumps. Trends Biochem Sci. 2014 Jan;39(1):8-16.

15. Roux F, Couraud PO. Rat brain endothelial cell lines for the study of blood-brain barrier permeability and transport functions. Cellular and molecular neurobiology. 2005 Feb;25(1):41-58.

16. Ohtsuki S, Hirayama M, Ito S, Uchida Y, Tachikawa M, Terasaki T. Quantitative targeted proteomics for understanding the blood-brain barrier: towards pharmacoproteomics. Expert Rev Proteomics. 2014 Jun;11(3):303-13.

17. Chaves C, Shawahna R, Jacob A, Scherrmann JM, Decleves X. Human ABC transporters at blood-CNS interfaces as determinants of CNS drug penetration. Curr Pharm Des. 2014;20(10):1450-62.

18. Soontornmalai A, Vlaming ML, Fritschy JM. Differential, strain-specific cellular and subcellular distribution of multidrug transporters in murine choroid plexus and blood-brain barrier. Neuroscience. 2006;138(1):159-69.

19. Uchida Y, Tachikawa M, Obuchi W, Hoshi Y, Tomioka Y, Ohtsuki S, et al. A study protocol for quantitative targeted absolute proteomics (QTAP) by LC-MS/MS: application for interstrain differences in protein expression levels of transporters, receptors, claudin-5, and marker proteins at the blood-brain barrier in $\mathrm{ddY}, \mathrm{FVB}$, and C57BL/6J mice. Fluids and barriers of the CNS. 2013;10(1):21.

20. Eyal S, Hsiao P, Unadkat JD. Drug interactions at the blood-brain barrier: fact or fantasy? Pharmacol Ther. 2009 Jul;123(1):80-104.

21. Tomi M, Hosoya K. The role of blood-ocular barrier transporters in retinal drug disposition: an overview. Expert Opin Drug Metab Toxicol. 2010 Sep;6(9):1111-24.

22. Zhang H, Song YN, Liu WG, Guo XL, Yu LG. Regulation and role of organic aniontransporting polypeptides (OATPs) in drug delivery at the choroid plexus. Journal of clinical neuroscience : official journal of the Neurosurgical Society of Australasia. 2010 Jun;17(6):679-84.

23. Dutheil F, Jacob A, Dauchy S, Beaune P, Scherrmann JM, Decleves X, et al. ABC transporters and cytochromes P450 in the human central nervous system: influence on brain pharmacokinetics and contribution to neurodegenerative disorders. Expert Opin Drug Metab Toxicol. 2010 Oct;6(10):1161-74.

24. Hartz AM, Bauer B. ABC transporters in the CNS - an inventory. Curr Pharm Biotechnol. 2011 Apr;12(4):656-73. 
25. Mahringer A, Ott M, Reimold I, Reichel V, Fricker G. The ABC of the blood-brain barrier regulation of drug efflux pumps. Curr Pharm Des. 2011;17(26):2762-70.

26. Pardridge WM. Drug transport across the blood-brain barrier. J Cereb Blood Flow Metab. 2012 Nov;32(11):1959-72.

27. Ashraf T, Kis O, Banerjee N, Bendayan R. Drug transporters at brain barriers: expression and regulation by neurological disorders. Adv Exp Med Biol. 2012;763:20-69.

28. Farthing CA, Sweet DH. Expression and function of organic cation and anion transporters (SLC22 family) in the CNS. Curr Pharm Des. 2014;20(10):1472-86.

29. Miller DS. ABC Transporter Regulation by Signaling at the Blood-Brain Barrier: Relevance to Pharmacology. Adv Pharmacol. 2014;71:1-24.

30. Ashraf T, Kao A, Bendayan R. Functional expression of drug transporters in glial cells: potential role on drug delivery to the CNS. Adv Pharmacol. 2014;71:45-111.

31. Saunders NR, Daneman R, Dziegielewska KM, Liddelow SA. Transporters of the blood-brain and blood-CSF interfaces in development and in the adult. Mol Aspects Med. 2013 AprJun;34(2-3):742-52.

32. Shawahna R, Uchida Y, Decleves X, Ohtsuki S, Yousif S, Dauchy S, et al. Transcriptomic and quantitative proteomic analysis of transporters and drug metabolizing enzymes in freshly isolated human brain microvessels. Mol Pharm. 2011 Aug 1;8(4):1332-41.

33. Virgintino D, Robertson D, Errede M, Benagiano V, Girolamo F, Maiorano E, et al. Expression of P-glycoprotein in human cerebral cortex microvessels. J Histochem Cytochem. 2002 Dec;50(12):1671-6.

34. Konig J. Uptake transporters of the human OATP family. Molecular characteristics, substrates, their role in drug-drug interactions, and functional consequences of polymorphisms. Handb Exp Pharmacol. 2011;201:1-28.

35. Roth M, Obaidat A, Hagenbuch B. OATPs, OATs and OCTs: The organic anion and cation transporters of the SLCO and SLC22A gene superfamilies. Br J Pharmacol. 2012 Oct 20;165:1260-87.

36. Burckhardt G. Drug transport by Organic Anion Transporters (OATs). Pharmacol Ther. 2012 Oct;136(1):106-30.

37. Koepsell H. The SLC22 family with transporters of organic cations, anions and zwitterions. Mol Aspects Med. 2013 Apr-Jun;34(2-3):413-35.

38. Wang L, Sweet DH. Renal organic anion transporters (SLC22 family): expression, regulation, roles in toxicity, and impact on injury and disease. AAPS J. 2013 Jan;15(1):53-69. 
39. Nies AT, Koepsell H, Damme K, Schwab M. Organic cation transporters (OCTs, MATEs), in vitro and in vivo evidence for the importance in drug therapy. Handb Exp Pharmacol. 2011;201:105-67.

40. Pastor-Anglada M, Cano-Soldado P, Errasti-Murugarren E, Casado FJ. SLC28 genes and concentrative nucleoside transporter (CNT) proteins. Xenobiotica. 2008 Jul;38(7-8):972-94.

41. Young JD, Yao SY, Baldwin JM, Cass CE, Baldwin SA. The human concentrative and equilibrative nucleoside transporter families, SLC28 and SLC29. Mol Aspects Med. 2013 Apr-Jun;34(2-3):529-47.

42. Young JD, Yao SY, Sun L, Cass CE, Baldwin SA. Human equilibrative nucleoside transporter (ENT) family of nucleoside and nucleobase transporter proteins. Xenobiotica. 2008 Jul;38(7-8):995-1021.

43. Motohashi H, Inui K. Organic cation transporter OCTs (SLC22) and MATEs (SLC47) in the human kidney. AAPS J. 2013 Apr;15(2):581-8.

44. Staud F, Cerveny L, Ahmadimoghaddam D, Ceckova M. Multidrug and toxin extrusion proteins (MATE/SLC47); role in pharmacokinetics. Int J Biochem Cell Biol. 2013 Sep;45(9):2007-11.

45. Ronaldson PT, Davis TP. Targeted drug delivery to treat pain and cerebral hypoxia. Pharmacol Rev. 2013 Jan;65(1):291-314.

46. Cheng $\mathrm{Z}$, Liu H, Yu N, Wang F, An G, Xu Y, et al. Hydrophilic anti-migraine triptans are substrates for OATP1A2, a transporter expressed at human blood-brain barrier. Xenobiotica. 2012 Sep;42(9):880-90.

47. Pouria S, de Andrade A, Barbosa J, Cavalcanti RL, Barreto VT, Ward CJ, et al. Fatal microcystin intoxication in haemodialysis unit in Caruaru, Brazil. Lancet. 1998 Jul 4;352(9121):21-6.

48. Fischer WJ, Altheimer S, Cattori V, Meier PJ, Dietrich DR, Hagenbuch B. Organic anion transporting polypeptides expressed in liver and brain mediate uptake of microcystin. Toxicol Appl Pharmacol. 2005;203(3):257-63.

49. Gao B, Vavricka SR, Meier PJ, Stieger B. Differential cellular expression of organic anion transporting peptides OATP1A2 and OATP2B1 in the human retina and brain: implications for carrier-mediated transport of neuropeptides and neurosteriods in the CNS. Pflugers Arch. 2014 Aug 19.

50. Runnegar M, Berndt N, Kaplowitz N. Microcystin uptake and inhibition of protein phosphatases: effects of chemoprotectants and self-inhibition in relation to known hepatic transporters. Toxicol Appl Pharmacol. 1995 Oct;134(2):264-72. 
51. Wirth EK, Schweizer U, Kohrle J. Transport of thyroid hormone in brain. Frontiers in endocrinology. 2014;5:98.

52. Roberts LM, Woodford K, Zhou M, Black DS, Haggerty JE, Tate EH, et al. Expression of the thyroid hormone transporters monocarboxylate transporter-8 (SLC16A2) and organic ion transporter-14 (SLCO1C1) at the blood-brain barrier. Endocrinology. 2008 Dec;149(12):6251-61.

53. Pizzagalli F, Hagenbuch B, Stieger B, Klenk U, Folkers G, Meier PJ. Identification of a novel human organic anion transporting polypeptide as a high affinity thyroxine transporter. Mol Endocrinol. 2002;16(10):2283-96.

54. Abbott NJ, Dolman DE, Patabendige AK. Assays to predict drug permeation across the blood-brain barrier, and distribution to brain. Curr Drug Metab. 2008 Nov;9(9):901-10.

55. Schinkel AH, Jonker JW. Mammalian drug efflux transporters of the ATP binding cassette (ABC) family: an overview. Adv Drug Deliv Rev. 2003 Jan 21;55(1):3-29.

56. Ueda K. ABC proteins protect the human body and maintain optimal health. Biosci Biotechnol Biochem. 2011;75(3):401-9.

57. Marzolini C, Paus E, Buclin T, Kim RB. Polymorphisms in human MDR1 (P-glycoprotein): recent advances and clinical relevance. Clin Pharmacol Ther. 2004 Jan;75(1):13-33.

58. Eckford PD, Sharom FJ. ABC efflux pump-based resistance to chemotherapy drugs. Chemical reviews. 2009 Jul;109(7):2989-3011.

59. Cascorbi I. P-glycoprotein: tissue distribution, substrates, and functional consequences of genetic variations. Handb Exp Pharmacol. 2011(201):261-83.

60. Keppler D. Multidrug resistance proteins (MRPs, ABCCs): Importance for pathophysiology and drug therapy. Handb Exp Pharmacol. 2011;201:299-323.

61. Meyer zu Schwabedissen HE, Kroemer HK. In vitro and in vivo evidence for the importance of breast cancer resistance protein transporters (BCRP/MXR/ABCP/ABCG2). Handb Exp Pharmacol. 2011(201):325-71.

62. Marquez B, Van Bambeke F. ABC Multidrug Transporters: Target for Modulation of Drug Pharmacokinetics and Drug-Drug Interactions. Curr Drug Targets. 2011 Nov 2;12(5):600-20.

63. Sharom FJ. The P-glycoprotein multidrug transporter. Essays Biochem. 2011 Sep 7;50(1):161-78.

64. Tamaki A, Ierano C, Szakacs G, Robey RW, Bates SE. The controversial role of ABC transporters in clinical oncology. Essays Biochem. 2011 Sep 7;50(1):209-32.

65. Fukuda Y, Schuetz JD. ABC transporters and their role in nucleoside and nucleotide drug resistance. Biochem Pharmacol. 2012 Apr 15;83(8):1073-83. 
66. Sissung TM, Troutman SM, Campbell TJ, Pressler HM, Sung H, Bates SE, et al. Transporter pharmacogenetics: transporter polymorphisms affect normal physiology, diseases, and pharmacotherapy. Discov Med. 2012 Jan;13(68):19-34.

67. van der Schoor LW, Verkade HJ, Kuipers F, Jonker JW. New insights in the biology of ABC transporters $\mathrm{ABCC} 2$ and $\mathrm{ABCC} 3$ : impact on drug disposition. Expert Opin Drug Metab Toxicol. 2014 Nov 7:1-21.

68. Yahanda AM, Alder KM, Fisher GA, Brophy NA, Halsey J, Hardy RI, et al. Phase I trial of etoposide with cyclosporine as a modulator of multidrug resistance. J Clin Oncol. 1992 Oct;10(10):1624-34.

69. Boote DJ, Dennis IF, Twentyman PR, Osborne RJ, Laburte C, Hensel S, et al. Phase I study of etoposide with SDZ PSC 833 as a modulator of multidrug resistance in patients with cancer. J Clin Oncol. 1996 Feb;14(2):610-8.

70. Lhomme C, Joly F, Walker JL, Lissoni AA, Nicoletto MO, Manikhas GM, et al. Phase III study of valspodar (PSC 833) combined with paclitaxel and carboplatin compared with paclitaxel and carboplatin alone in patients with stage IV or suboptimally debulked stage III epithelial ovarian cancer or primary peritoneal cancer. J Clin Oncol. 2008 Jun 1;26(16):267482.

71. Trump DL, Smith DC, Ellis PG, Rogers MP, Schold SC, Winer EP, et al. High-dose oral tamoxifen, a potential multidrug-resistance-reversal agent: phase I trial in combination with vinblastine. J Natl Cancer Inst. 1992 Dec 2;84(23):1811-6.

72. Gao B, Meier PJ. Organic anion transport across the choroid plexus. Microsc Res Tech. 2001;52(1):60-4.

73. Kusuhara H, Sugiyama Y. Efflux transport systems for organic anions and cations at the blood-CSF barrier. Adv Drug Deliv Rev. 2004 Oct 14;56(12):1741-63.

74. Brinker T, Stopa E, Morrison J, Klinge P. A new look at cerebrospinal fluid circulation. Fluids and barriers of the CNS. 2014;11:10.

75. Chikly B, Quaghebeur J. Reassessing cerebrospinal fluid (CSF) hydrodynamics: a literature review presenting a novel hypothesis for CSF physiology. Journal of bodywork and movement therapies. $2013 \mathrm{Jul} ; 17(3): 344-54$.

76. Hosoya K, Tachikawa M. The inner blood-retinal barrier: molecular structure and transport biology. Adv Exp Med Biol. 2012;763:85-104.

77. Keren G, Alhalel A, Bartov E, Kitzes-Cohen R, Rubinstein E, Segev S, et al. The intravitreal penetration of orally administered ciprofloxacin in humans. Invest Ophthalmol Vis Sci. 1991 Jul;32(8):2388-92. 
78. Sheridan KR, Potoski BA, Shields RK, Nau GJ. Presence of adequate intravitreal concentrations of daptomycin after systemic intravenous administration in a patient with endogenous endophthalmitis. Pharmacotherapy. 2010 Dec;30(12):1247-51.

79. Xiao Y, Deng J, Liu X, Huang J, Sun Y, Dai R, et al. Different binding sites of bovine organic anion-transporting polypeptide1a2 are involved in the transport of different fluoroquinolones. Drug Metab Dispos. 2014 Aug;42(8):1261-7.

80. Alm A. Latanoprost in the treatment of glaucoma. Clinical ophthalmology. 2014;8:1967-85.

81. Hagenbuch B. Cellular entry of thyroid hormones by organic anion transporting polypeptides. Best Pract Res Clin Endocrinol Metab. 2007 Jun;21(2):209-21.

82. Kraft ME, Glaeser H, Mandery K, Konig J, Auge D, Fromm MF, et al. The prostaglandin transporter OATP2A1 is expressed in human ocular tissues and transports the antiglaucoma prostanoid latanoprost. Invest Ophthalmol Vis Sci. 2010 May;51(5):2504-11.

83. Pappenheimer JR, Heisey SR, Jordan EF. Active transport of Diodrast and phenolsulfonphthalein from cerebrospinal fluid to blood. Am J Physiol. 1961 Jan;200:1-10.

84. Schinkel AH, Smit JJ, van Tellingen O, Beijnen JH, Wagenaar E, van Deemter L, et al. Disruption of the mouse mdr1a P-glycoprotein gene leads to a deficiency in the blood-brain barrier and to increased sensitivity to drugs. Cell. 1994 May 20;77(4):491-502.

85. Schinkel AH, Mayer U, Wagenaar E, Mol CA, van Deemter L, Smit JJ, et al. Normal viability and altered pharmacokinetics in mice lacking mdr1-type (drug-transporting) P-glycoproteins. Proc Natl Acad Sci U S A. 1997 Apr 15;94(8):4028-33.

86. Vlaming ML, Lagas JS, Schinkel AH. Physiological and pharmacological roles of ABCG2 (BCRP): recent findings in Abcg2 knockout mice. Adv Drug Deliv Rev. 2009 Jan 31;61(1):14-25.

87. Ose A, Kusuhara H, Endo C, Tohyama K, Miyajima M, Kitamura S, et al. Functional characterization of mouse organic anion transporting peptide 1a4 in the uptake and efflux of drugs across the blood-brain barrier. Drug Metab Dispos. 2010 Jan;38(1):168-76.

88. Higgins JW, Bao JQ, Ke AB, Manro JR, Fallon JK, Smith PC, et al. Utility of Oatp1a/1bknockout and OATP1B1/3-humanized mice in the study of OATP-mediated pharmacokinetics and tissue distribution: case studies with pravastatin, atorvastatin, simvastatin, and carboxydichlorofluorescein. Drug Metab Dispos. 2014 Jan;42(1):182-92.

89. Gubareva LV, Kaiser L, Hayden FG. Influenza virus neuraminidase inhibitors. Lancet. 2000 Mar 4;355(9206):827-35. 
90. Jefferson T, Jones MA, Doshi P, Del Mar CB, Hama R, Thompson MJ, et al. Neuraminidase inhibitors for preventing and treating influenza in healthy adults and children. Cochrane Database Syst Rev. 2014;4:CD008965.

91. Satoh T, Taylor P, Bosron WF, Sanghani SP, Hosokawa M, La Du BN. Current progress on esterases: from molecular structure to function. Drug Metab Dispos. 2002 May;30(5):488-93.

92. Ose A, Kusuhara H, Yamatsugu K, Kanai M, Shibasaki M, Fujita T, et al. P-glycoprotein restricts the penetration of oseltamivir across the blood-brain barrier. Drug Metab Dispos. $2008 \mathrm{Feb} ; 36(2): 427-34$.

93. Ose A, Ito M, Kusuhara H, Yamatsugu K, Kanai M, Shibasaki M, et al. Limited brain distribution of [3R,4R,5S]-4-acetamido-5-amino-3-(1-ethylpropoxy)-1-cyclohexene-1carboxylate phosphate (Ro 64-0802), a pharmacologically active form of oseltamivir, by active efflux across the blood-brain barrier mediated by organic anion transporter 3 (Oat3/Slc22a8) and multidrug resistance-associated protein 4 (Mrp4/Abcc4). Drug Metab Dispos. 2009 Feb;37(2):315-21.

94. Shen J, Carcaboso AM, Hubbard KE, Tagen M, Wynn HG, Panetta JC, et al. Compartmentspecific roles of ATP-binding cassette transporters define differential topotecan distribution in brain parenchyma and cerebrospinal fluid. Cancer Res. 2009 Jul 15;69(14):5885-92.

95. Sweet DH, Miller DS, Pritchard JB, Fujiwara Y, Beier DR, Nigam SK. Impaired organic anion transport in kidney and choroid plexus of organic anion transporter 3 (Oat3 (Slc22a8)) knockout mice. J Biol Chem. 2002 Jul 26;277(30):26934-43.

96. Keep RF, Smith DE. Choroid plexus transport: gene deletion studies. Fluids and barriers of the CNS. 2011;8(1):26.

97. Mayerl S, Visser TJ, Darras VM, Horn S, Heuer H. Impact of oatp1c1 deficiency on thyroid hormone metabolism and action in the mouse brain. Endocrinology. 2012 Mar;153(3):152837.

98. Schnell C, Shahmoradi A, Wichert SP, Mayerl S, Hagos Y, Heuer H, et al. The multispecific thyroid hormone transporter OATP1C1 mediates cell-specific sulforhodamine 101-labeling of hippocampal astrocytes. Brain structure \& function. 2013 Oct 16.

99. Marx V. Proteomics: An atlas of expression. Nature. 2014 May 29;509(7502):645-9.

100. Stieger B, Unadkat JD, Prasad B, Langer O, Gali H. Role of (drug) transporters in imaging in health and disease. Drug Metab Dispos. 2014 Dec;42(12):2007-15.

101. Bauer M, Karch R, Zeitlinger M, Stanek J, Philippe C, Wadsak W, et al. Interaction of 11Ctariquidar and 11C-elacridar with P-glycoprotein and breast cancer resistance protein at the human blood-brain barrier. J Nucl Med. 2013 Aug;54(8):1181-7. 
102. Feldmann M, Asselin MC, Liu J, Wang S, McMahon A, Anton-Rodriguez J, et al. Pglycoprotein expression and function in patients with temporal lobe epilepsy: a case-control study. Lancet Neurol. 2013 Aug;12(8):777-85.

103. Bauer M, Karch R, Zeitlinger M, Liu J, Koepp MJ, Asselin MC, et al. In vivo P-glycoprotein function before and after epilepsy surgery. Neurology. 2014 Oct 7;83(15):1326-31.

104. Mairinger S, Erker T, Muller M, Langer O. PET and SPECT radiotracers to assess function and expression of ABC transporters in vivo. Curr Drug Metab. 2011 Oct;12(8):774-92.

105. Pike VW. PET radiotracers: crossing the blood-brain barrier and surviving metabolism. Trends Pharmacol Sci. 2009 Aug;30(8):431-40.

106. Kalvass JC, Polli JW, Bourdet DL, Feng B, Huang SM, Liu X, et al. Why clinical modulation of efflux transport at the human blood-brain barrier is unlikely: the ITC evidence-based position. Clin Pharmacol Ther. 2013 Jul;94(1):80-94.

107. Hsiao P, Unadkat JD. Predicting the outer boundaries of P-glycoprotein (P-gp)-based drug interactions at the human blood-brain barrier based on rat studies. Mol Pharm. 2014 Feb $3 ; 11(2): 436-44$.

108. Kullak-Ublick GA, Hagenbuch B, Stieger B, Schteingart CD, Hofmann AF, Wolkoff AW, et al. Molecular and functional characterization of an organic anion transporting polypeptide cloned from human liver. Gastroenterology. 1995;109:1274-82.

109. Kullak-Ublick GA, Fisch T, Oswald M, Hagenbuch B, Meier PJ, Beuers U, et al. Dehydroepiandrosterone sulfate (DHEAS): identification of a carrier protein in human liver and brain. FEBS Lett. 1998;424(3):173-6.

110. Gao B, Hagenbuch B, Kullak-Ublick GA, Benke D, Aguzzi A, Meier PJ. Organic aniontransporting polypeptides mediate transport of opioid peptides across blood-brain barrier. $\mathbf{J}$ Pharmacol Exp Ther. 2000 Jul;294:73-9.

111. Ji C, Tschantz WR, Pfeifer ND, Ullah M, Sadagopan N. Development of a multiplex UPLCMRM MS method for quantification of human membrane transport proteins OATP1B1, OATP1B3 and OATP2B1 in in vitro systems and tissues. Anal Chim Acta. 2012 Mar 2;717:67-76.

112. Noe B, Hagenbuch B, Stieger B, Meier PJ. Isolation of a multispecific organic anion and cardiac glycoside transporter from rat brain. Proc Natl Acad Sci U S A. 1997;94(19):1034650.

113. Roberts LM, Black DS, Raman C, Woodford K, Zhou M, Haggerty JE, et al. Subcellular localization of transporters along the rat blood-brain barrier and blood-cerebral-spinal fluid barrier by in vivo biotinylation. Neuroscience. 2008 Aug 13;155(2):423-38. 
114. Gao B, Stieger B, Noe B, Fritschy JM, Meier PJ. Localization of the organic anion transporting polypeptide 2 (Oatp2) in capillary endothelium and choroid plexus epithelium of rat brain. J Histochem Cytochem. 1999 Oct;47(10):1255-64.

115. Chu C, Li JY, Boado RJ, Pardridge WM. Blood-brain barrier genomics and cloning of a novel organic anion transporter. J Cereb Blood Flow Metab. 2008 Feb;28(2):291-301.

116. Enerson BE, Drewes LR. The rat blood-brain barrier transcriptome. J Cereb Blood Flow Metab. $2006 \mathrm{Jul} ; 26(7): 959-73$.

117. Sugiyama D, Kusuhara H, Taniguchi H, Ishikawa S, Nozaki Y, Aburatani H, et al. Functional characterization of rat brain-specific organic anion transporter (Oatp14) at the blood-brain barrier: high affinity transporter for thyroxine. J Biol Chem. 2003 Oct 31;278(44):43489-95.

118. Nishio T, Adachi H, Nakagomi R, Tokui T, Sato E, Tanemoto M, et al. Molecular identification of a rat novel organic anion transporter moat1, which transports prostaglandin D(2), leukotriene C(4), and taurocholate. Biochem Biophys Res Commun. 2000 Sep $7 ; 275(3): 831-8$.

119. Ohtsuki S, Takizawa T, Takanaga H, Hori S, Hosoya K, Terasaki T. Localization of organic anion transporting polypeptide 3 (oatp3) in mouse brain parenchymal and capillary endothelial cells. J Neurochem. 2004 Aug;90(3):743-9.

120. Daneman R, Zhou L, Agalliu D, Cahoy JD, Kaushal A, Barres BA. The mouse blood-brain barrier transcriptome: a new resource for understanding the development and function of brain endothelial cells. PLoS One. 2010;5(10):e13741.

121. Kamiie J, Ohtsuki S, Iwase R, Ohmine K, Katsukura Y, Yanai K, et al. Quantitative atlas of membrane transporter proteins: development and application of a highly sensitive simultaneous LC/MS/MS method combined with novel in-silico peptide selection criteria. Pharm Res. 2008 Jun;25(6):1469-83.

122. Akanuma S, Uchida Y, Ohtsuki S, Tachikawa M, Terasaki T, Hosoya K. Attenuation of prostaglandin E2 elimination across the mouse blood-brain barrier in lipopolysaccharideinduced inflammation and additive inhibitory effect of cefmetazole. Fluids and barriers of the CNS. 2011;8:24.

123. Uchida Y, Ohtsuki S, Katsukura Y, Ikeda C, Suzuki T, Kamiie J, et al. Quantitative targeted absolute proteomics of human blood-brain barrier transporters and receptors. J Neurochem. 2011 Apr;117(2):333-45.

124. Agarwal S, Uchida Y, Mittapalli RK, Sane R, Terasaki T, Elmquist WF. Quantitative proteomics of transporter expression in brain capillary endothelial cells isolated from $\mathrm{P}$ - 
glycoprotein (P-gp), breast cancer resistance protein (Bcrp), and P-gp/Bcrp knockout mice. Drug Metab Dispos. 2012 Jun;40(6):1164-9.

125. Uchida Y, Ohtsuki S, Terasaki T. Pharmacoproteomics-based reconstruction of in vivo Pglycoprotein function at blood-brain barrier and brain distribution of substrate verapamil in pentylenetetrazole-kindled epilepsy, spontaneous epilepsy, and phenytoin treatment models. Drug Metab Dispos. 2014 Oct;42(10):1719-26.

126. Dahlin A, Royall J, Hohmann JG, Wang J. Expression profiling of the solute carrier gene family in the mouse brain. J Pharmacol Exp Ther. 2009 May;329(2):558-70.

127. Muller J, Heuer H. Expression pattern of thyroid hormone transporters in the postnatal mouse brain. Frontiers in endocrinology. 2014;5:92.

128. Bleasby K, Castle JC, Roberts CJ, Cheng C, Bailey WJ, Sina JF, et al. Expression profiles of 50 xenobiotic transporter genes in humans and pre-clinical species: a resource for investigations into drug disposition. Xenobiotica. 2006 Oct-Nov;36(10-11):963-88.

129. Lin CJ, Tai Y, Huang MT, Tsai YF, Hsu HJ, Tzen KY, et al. Cellular localization of the organic cation transporters, OCT1 and OCT2, in brain microvessel endothelial cells and its implication for MPTP transport across the blood-brain barrier and MPTP-induced dopaminergic toxicity in rodents. J Neurochem. 2010 Aug;114(3):717-27.

130. Taubert D, Grimberg G, Stenzel W, Schomig E. Identification of the endogenous key substrates of the human organic cation transporter OCT2 and their implication in function of dopaminergic neurons. PLoS One. 2007;2(4):e385.

131. Geier EG, Chen EC, Webb A, Papp AC, Yee SW, Sadee W, et al. Profiling solute carrier transporters in the human blood-brain barrier. Clin Pharmacol Ther. 2013 Dec;94(6):636-9.

132. Kido Y, Tamai I, Ohnari A, Sai Y, Kagami T, Nezu J, et al. Functional relevance of carnitine transporter OCTN2 to brain distribution of L-carnitine and acetyl-L-carnitine across the blood-brain barrier. J Neurochem. 2001 Dec;79(5):959-69.

133. Amphoux A, Vialou V, Drescher E, Bruss M, Mannoury La Cour C, Rochat C, et al. Differential pharmacological in vitro properties of organic cation transporters and regional distribution in rat brain. Neuropharmacology. 2006 Jun;50(8):941-52.

134. Mooslehner KA, Allen ND. Cloning of the mouse organic cation transporter 2 gene, Slc22a2, from an enhancer-trap transgene integration locus. Mamm Genome. 1999 Mar;10(3):218-24.

135. Naud J, Laurin LP, Michaud J, Beauchemin S, Leblond FA, Pichette V. Effects of chronic renal failure on brain drug transporters in rats. Drug Metab Dispos. 2012 Jan;40(1):39-46.

136. Ohtsuki S, Asaba H, Takanaga H, Deguchi T, Hosoya K, Otagiri M, et al. Role of blood-brain barrier organic anion transporter 3 (OAT3) in the efflux of indoxyl sulfate, a uremic toxin: its 
involvement in neurotransmitter metabolite clearance from the brain. J Neurochem. 2002 Oct;83(1):57-66.

137. Hoshi Y, Uchida Y, Tachikawa M, Inoue T, Ohtsuki S, Terasaki T. Quantitative atlas of blood-brain barrier transporters, receptors, and tight junction proteins in rats and common marmoset. J Pharm Sci. 2013 Sep;102(9):3343-55.

138. Mori S, Takanaga H, Ohtsuki S, Deguchi T, Kang YS, Hosoya K, et al. Rat organic anion transporter 3 (rOAT3) is responsible for brain-to-blood efflux of homovanillic acid at the abluminal membrane of brain capillary endothelial cells. J Cereb Blood Flow Metab. 2003 Apr;23(4):432-40.

139. Ohtsuki S, Kikkawa T, Mori S, Hori S, Takanaga H, Otagiri M, et al. Mouse reduced in osteosclerosis transporter functions as an organic anion transporter 3 and is localized at abluminal membrane of blood-brain barrier. J Pharmacol Exp Ther. 2004 Jun;309(3):1273-81.

140. Li JY, Boado RJ, Pardridge WM. Cloned blood-brain barrier adenosine transporter is identical to the rat concentrative Na+ nucleoside cotransporter CNT2. J Cereb Blood Flow Metab. 2001 Aug;21(8):929-36.

141. Ohtsuki S, Ikeda C, Uchida Y, Sakamoto Y, Miller F, Glacial F, et al. Quantitative targeted absolute proteomic analysis of transporters, receptors and junction proteins for validation of human cerebral microvascular endothelial cell line hCMEC/D3 as a human blood-brain barrier model. Mol Pharm. 2013 Jan 7;10(1):289-96.

142. Warren MS, Zerangue N, Woodford K, Roberts LM, Tate EH, Feng B, et al. Comparative gene expression profiles of $\mathrm{ABC}$ transporters in brain microvessel endothelial cells and brain in five species including human. Pharmacological Research. 2009 Jun;59(6):404-13.

143. Cooray HC, Blackmore CG, Maskell L, Barrand MA. Localisation of breast cancer resistance protein in microvessel endothelium of human brain. Neuroreport. 2002 Nov 15;13(16):205963.

144. Daood M, Tsai C, Ahdab-Barmada M, Watchko JF. ABC transporter (P-gp/ABCB1, MRP1/ABCC1, BCRP/ABCG2) expression in the developing human CNS. Neuropediatrics. 2008 Aug;39(4):211-8.

145. Gazzin S, Strazielle N, Schmitt C, Fevre-Montange M, Ostrow JD, Tiribelli C, et al. Differential expression of the multidrug resistance-related proteins $\mathrm{ABCb} 1$ and $\mathrm{ABCc} 1$ between blood-brain interfaces. J Comp Neurol. 2008 Oct 10;510(5):497-507.

146. Nies AT, Jedlitschky G, Konig J, Herold-Mende C, Steiner HH, Schmitt HP, et al. Expression and immunolocalization of the multidrug resistance proteins, MRP1-MRP6 (ABCC1ABCC6), in human brain. Neuroscience. 2004;129(2):349-60. 
147. Hori S, Ohtsuki S, Tachikawa M, Kimura N, Kondo T, Watanabe M, et al. Functional expression of rat $\mathrm{ABCG} 2$ on the luminal side of brain capillaries and its enhancement by astrocyte-derived soluble factor(s). J Neurochem. 2004 Aug;90(3):526-36.

148. Stewart PA, Beliveau R, Rogers KA. Cellular localization of P-glycoprotein in brain versus gonadal capillaries. J Histochem Cytochem. 1996 Jul;44(7):679-85.

149. Regina A, Koman A, Piciotti M, El Hafny B, Center MS, Bergmann R, et al. Mrp1 multidrug resistance-associated protein and P-glycoprotein expression in rat brain microvessel endothelial cells. J Neurochem. 1998 Aug;71(2):705-15.

150. Miller DS, Nobmann SN, Gutmann H, Toeroek M, Drewe J, Fricker G. Xenobiotic transport across isolated brain microvessels studied by confocal microscopy. Mol Pharmacol. 2000 Dec;58(6):1357-67.

151. Bauer B, Hartz AM, Lucking JR, Yang X, Pollack GM, Miller DS. Coordinated nuclear receptor regulation of the efflux transporter, Mrp2, and the phase-II metabolizing enzyme, GSTpi, at the blood-brain barrier. J Cereb Blood Flow Metab. 2008 Jun;28(6):1222-34.

152. Yousif S, Marie-Claire C, Roux F, Scherrmann JM, Decleves X. Expression of drug transporters at the blood-brain barrier using an optimized isolated rat brain microvessel strategy. Brain Res. 2007 Feb 23;1134(1):1-11.

153. Leggas M, Adachi M, Scheffer GL, Sun D, Wielinga P, Du G, et al. Mrp4 confers resistance to topotecan and protects the brain from chemotherapy. Mol Cell Biol. 2004 Sep;24(17):761221.

154. Cisternino S, Mercier C, Bourasset F, Roux F, Scherrmann JM. Expression, up-regulation, and transport activity of the multidrug-resistance protein Abcg2 at the mouse blood-brain barrier. Cancer Res. 2004 May 1;64(9):3296-301.

155. Harati R, Benech H, Villegier AS, Mabondzo A. P-glycoprotein, breast cancer resistance protein, Organic Anion Transporter 3, and Transporting Peptide 1a4 during blood-brain barrier maturation: involvement of Wnt/beta-catenin and endothelin-1 signaling. Mol Pharm. 2013 May 6;10(5):1566-80.

156. Tachikawa M, Watanabe M, Hori S, Fukaya M, Ohtsuki S, Asashima T, et al. Distinct spatiotemporal expression of $\mathrm{ABCA}$ and $\mathrm{ABCG}$ transporters in the developing and adult mouse brain. J Neurochem. 2005 Oct;95(1):294-304.

157. Tsai CE, Daood MJ, Lane RH, Hansen TW, Gruetzmacher EM, Watchko JF. P-glycoprotein expression in mouse brain increases with maturation. Biology of the neonate. 2002 Jan;81(1):58-64. 
158. Murugesan N, Macdonald JA, Lu Q, Wu SL, Hancock WS, Pachter JS. Analysis of mouse brain microvascular endothelium using laser capture microdissection coupled with proteomics. Methods Mol Biol. 2011;686:297-311.

159. Huber RD, Gao B, Sidler Pfandler MA, Zhang-Fu W, Leuthold S, Hagenbuch B, et al. Characterization of two splice variants of human organic anion transporting polypeptide 3A1 isolated from human brain. Am J Physiol Cell Physiol. 2007 Feb;292(2):C795-806.

160. Angeletti RH, Novikoff PM, Juvvadi SR, Fritschy JM, Meier PJ, Wolkoff AW. The choroid plexus epithelium is the site of the organic anion transport protein in the brain. Proc Natl Acad Sci U S A. 1997 Jan 7;94(1):283-6.

161. Kusuhara H, He Z, Nagata Y, Nozaki Y, Ito T, Masuda H, et al. Expression and functional involvement of organic anion transporting polypeptide subtype 3 (Slc21a7) in rat choroid plexus. Pharm Res. 2003 May;20(5):720-7.

162. Ohtsuki S, Takizawa T, Takanaga H, Terasaki N, Kitazawa T, Sasaki M, et al. In vitro study of the functional expression of organic anion transporting polypeptide 3 at rat choroid plexus epithelial cells and its involvement in the cerebrospinal fluid-to-blood transport of estrone-3sulfate. Mol Pharmacol. 2003 Mar;63(3):532-7.

163. Sathyanesan M, Girgenti MJ, Banasr M, Stone K, Bruce C, Guilchicek E, et al. A molecular characterization of the choroid plexus and stress-induced gene regulation. Translational psychiatry. 2012;2:e139.

164. Abe T, Kakyo M, Sakagami H, Tokui T, Nishio T, Tanemoto M, et al. Molecular characterization and tissue distribution of a new organic anion transporter subtype (oatp3) that transports thyroid hormones and taurocholate and comparison with oatp2. J Biol Chem. 1998 Aug 28;273(35):22395-401.

165. Choudhuri S, Cherrington NJ, Li N, Klaassen CD. Constitutive expression of various xenobiotic and endobiotic transporter mRNAs in the choroid plexus of rats. Drug Metab Dispos. 2003 Nov;31(11):1337-45.

166. Ghersi-Egea JF, Strazielle N, Murat A, Jouvet A, Buenerd A, Belin MF. Brain protection at the blood-cerebrospinal fluid interface involves a glutathione-dependent metabolic barrier mechanism. J Cereb Blood Flow Metab. 2006 Sep;26(9):1165-75.

167. Kratzer I, Liddelow SA, Saunders NR, Dziegielewska KM, Strazielle N, Ghersi-Egea JF. Developmental changes in the transcriptome of the rat choroid plexus in relation to neuroprotection. Fluids and barriers of the CNS. 2013;10(1):25. 
168. Liddelow SA, Dziegielewska KM, Ek CJ, Habgood MD, Bauer H, Bauer HC, et al. Mechanisms that determine the internal environment of the developing brain: a transcriptomic, functional and ultrastructural approach. PLoS One. 2013;8(7):e65629.

169. Kis B, Isse T, Snipes JA, Chen L, Yamashita H, Ueta Y, et al. Effects of LPS stimulation on the expression of prostaglandin carriers in the cells of the blood-brain and blood-cerebrospinal fluid barriers. Journal of applied physiology. 2006 Apr;100(4):1392-9.

170. Marques F, Sousa JC, Coppola G, Gao F, Puga R, Brentani H, et al. Transcriptome signature of the adult mouse choroid plexus. Fluids and barriers of the CNS. 2011;8(1):10.

171. Tohyama K, Kusuhara H, Sugiyama Y. Involvement of multispecific organic anion transporter, Oatp14 (Slc21a14), in the transport of thyroxine across the blood-brain barrier. Endocrinology. 2004 Sep;145(9):4384-91.

172. Sweet DH, Miller DS, Pritchard JB. Ventricular choline transport: a role for organic cation transporter 2 expressed in choroid plexus. J Biol Chem. 2001 Nov 9;276(45):41611-9.

173. Nakayama H, Kitaichi K, Ito Y, Hashimoto K, Takagi K, Yokoi T, et al. The role of organic cation transporter-3 in methamphetamine disposition and its behavioral response in rats. Brain Res. 2007 Dec 12;1184:260-9.

174. Lamhonwah AM, Hawkins CE, Tam C, Wong J, Mai L, Tein I. Expression patterns of the organic cation/carnitine transporter family in adult murine brain. Brain \& development. 2008 Jan;30(1):31-42.

175. Alebouyeh M, Takeda M, Onozato ML, Tojo A, Noshiro R, Hasannejad H, et al. Expression of human organic anion transporters in the choroid plexus and their interactions with neurotransmitter metabolites. J Pharmacol Sci. 2003 Dec;93(4):430-6.

176. Nagata Y, Kusuhara H, Endou H, Sugiyama Y. Expression and functional characterization of rat organic anion transporter 3 (rOat3) in the choroid plexus. Mol Pharmacol. 2002 May;61(5):982-8.

177. Nagle MA, Wu W, Eraly SA, Nigam SK. Organic anion transport pathways in antiviral handling in choroid plexus in Oat1 (Slc22a6) and Oat3 (Slc22a8) deficient tissue. Neurosci Lett. 2013 Feb 8;534:133-8.

178. Redzic ZB, Biringer J, Barnes K, Baldwin SA, Al-Sarraf H, Nicola PA, et al. Polarized distribution of nucleoside transporters in rat brain endothelial and choroid plexus epithelial cells. J Neurochem. 2005 Sep;94(5):1420-6.

179. Redzic ZB, Malatiali SA, Grujicic D, Isakovic AJ. Expression and functional activity of nucleoside transporters in human choroid plexus. Cerebrospinal fluid research. 2010;7:2. 
180. Anderson CM, Xiong W, Geiger JD, Young JD, Cass CE, Baldwin SA, et al. Distribution of equilibrative, nitrobenzylthioinosine-sensitive nucleoside transporters (ENT1) in brain. J Neurochem. 1999 Aug;73(2):867-73.

181. Anderson CM, Baldwin SA, Young JD, Cass CE, Parkinson FE. Distribution of mRNA encoding a nitrobenzylthioinosine-insensitive nucleoside transporter (ENT2) in rat brain. Brain Res Mol Brain Res. 1999 Jul 5;70(2):293-7.

182. Berger UV, Hediger MA. Distribution of peptide transporter PEPT2 mRNA in the rat nervous system. Anatomy and embryology. 1999 May;199(5):439-49.

183. Novotny A, Xiang J, Stummer W, Teuscher NS, Smith DE, Keep RF. Mechanisms of 5aminolevulinic acid uptake at the choroid plexus. J Neurochem. 2000 Jul;75(1):321-8.

184. Shen H, Smith DE, Keep RF, Brosius FC, 3rd. Immunolocalization of the proton-coupled oligopeptide transporter PEPT2 in developing rat brain. Mol Pharm. 2004 Jul-Aug;1(4):24856.

185. Niehof M, Borlak J. Expression of HNF4alpha in the human and rat choroid plexus: implications for drug transport across the blood-cerebrospinal-fluid (CSF) barrier. BMC Mol Biol. 2009; 10:68.

186. Rao VV, Dahlheimer JL, Bardgett ME, Snyder AZ, Finch RA, Sartorelli AC, et al. Choroid plexus epithelial expression of MDR1 P glycoprotein and multidrug resistance-associated protein contribute to the blood-cerebrospinal-fluid drug-permeability barrier. Proc Natl Acad Sci U S A. 1999 Mar 30;96(7):3900-5.

187. Ek CJ, Wong A, Liddelow SA, Johansson PA, Dziegielewska KM, Saunders NR. Efflux mechanisms at the developing brain barriers: ABC-transporters in the fetal and postnatal rat. Toxicol Lett. 2010 Aug 1;197(1):51-9.

188. Reichel V, Burghard S, John I, Huber O. P-glycoprotein and breast cancer resistance protein expression and function at the blood-brain barrier and blood-cerebrospinal fluid barrier (choroid plexus) in streptozotocin-induced diabetes in rats. Brain Res. 2011 Jan 25;1370:23845 .

189. Nishino J, Suzuki H, Sugiyama D, Kitazawa T, Ito K, Hanano M, et al. Transepithelial transport of organic anions across the choroid plexus: possible involvement of organic anion transporter and multidrug resistance-associated protein. J Pharmacol Exp Ther. 1999 Jul;290(1):289-94.

190. Mercier C, Masseguin C, Roux F, Gabrion J, Scherrmann JM. Expression of P-glycoprotein (ABCB1) and Mrp1 (ABCC1) in adult rat brain: focus on astrocytes. Brain Res. 2004 Sep 17;1021(1):32-40. 
191. Reichel V, Klas J, Fricker G, Masereeuw R. Fluo-cAMP is transported by multidrug resistance-associated protein isoform 4 in rat choroid plexus. J Neurochem. 2010 Oct;115(1):200-8.

192. Liddelow SA, Temple S, Mollgard K, Gehwolf R, Wagner A, Bauer H, et al. Molecular characterisation of transport mechanisms at the developing mouse blood-CSF interface: a transcriptome approach. PLoS One. 2012;7(3):e33554.

193. Wijnholds J, deLange EC, Scheffer GL, van den Berg DJ, Mol CA, van der Valk M, et al. Multidrug resistance protein 1 protects the choroid plexus epithelium and contributes to the blood-cerebrospinal fluid barrier. J Clin Invest. 2000 Feb;105(3):279-85.

194. Dahlin A, Geier E, Stocker SL, Cropp CD, Grigorenko E, Bloomer M, et al. Gene expression profiling of transporters in the solute carrier and ATP-binding cassette superfamilies in human eye substructures. Mol Pharm. 2013 Feb 4;10(2):650-63.

195. Kadam RS, Ramamoorthy P, LaFlamme DJ, McKinsey TA, Kompella UB. Hypoxia alters ocular drug transporter expression and activity in rat and calf models: implications for drug delivery. Mol Pharm. 2013 Jun 3;10(6):2350-61.

196. Ito A, Yamaguchi K, Onogawa T, Unno M, Suzuki T, Nishio T, et al. Distribution of organic anion-transporting polypeptide 2 (oatp2) and oatp3 in the rat retina. Invest Ophthalmol Vis Sci. 2002 Mar;43(3):858-63.

197. Tomi M, Hosoya K. Application of magnetically isolated rat retinal vascular endothelial cells for the determination of transporter gene expression levels at the inner blood-retinal barrier. $\mathrm{J}$ Neurochem. 2004 Dec;91(5):1244-8.

198. Akanuma S, Hirose S, Tachikawa M, Hosoya K. Localization of organic anion transporting polypeptide (Oatp) 1a4 and Oatp1c1 at the rat blood-retinal barrier. Fluids and barriers of the CNS. 2013;10(1):29.

199. Gao B, Wenzel A, Grimm C, Vavricka SR, Benke D, Meier PJ, et al. Localization of organic anion transport protein 2 in the apical region of rat retinal pigment epithelium. Invest Ophthalmol Vis Sci. 2002;43(2):510-4.

200. Walters HC, Craddock AL, Fusegawa H, Willingham MC, Dawson PA. Expression, transport properties, and chromosomal location of organic anion transporter subtype 3. Am J Physiol Gastrointest Liver Physiol. 2000;279(6):G1188-200.

201. Ito A, Yamaguchi K, Tomita H, Suzuki T, Onogawa T, Sato T, et al. Distribution of rat organic anion transporting polypeptide-E (oatp-E) in the rat eye. Invest Ophthalmol Vis Sci. 2003 Nov;44(11):4877-84. 
202. Kadam RS, Vooturi SK, Kompella UB. Immunohistochemical and functional characterization of peptide, organic cation, neutral and basic amino acid, and monocarboxylate drug transporters in human ocular tissues. Drug Metab Dispos. 2013 Feb;41(2):466-74.

203. Rajan PD, Kekuda R, Chancy CD, Huang W, Ganapathy V, Smith SB. Expression of the extraneuronal monoamine transporter in RPE and neural retina. Curr Eye Res. 2000 Mar;20(3):195-204.

204. Tachikawa M, Takeda Y, Tomi M, Hosoya K. Involvement of OCTN2 in the transport of acetyl-L-carnitine across the inner blood-retinal barrier. Invest Ophthalmol Vis Sci. 2010 Jan;51(1):430-6.

205. Hosoya K, Makihara A, Tsujikawa Y, Yoneyama D, Mori S, Terasaki T, et al. Roles of inner blood-retinal barrier organic anion transporter 3 in the vitreous/retina-to-blood efflux transport of p-aminohippuric acid, benzylpenicillin, and 6-mercaptopurine. J Pharmacol Exp Ther. 2009 Apr;329(1):87-93.

206. Kennedy BG, Mangini NJ. P-glycoprotein expression in human retinal pigment epithelium. Mol Vis. 2002 Nov 11;8:422-30.

207. Aukunuru JV, Sunkara G, Bandi N, Thoreson WB, Kompella UB. Expression of multidrug resistance-associated protein (MRP) in human retinal pigment epithelial cells and its interaction with BAPSG, a novel aldose reductase inhibitor. Pharm Res. 2001 May;18(5):56572.

208. Holash JA, Stewart PA. The relationship of astrocyte-like cells to the vessels that contribute to the blood-ocular barriers. Brain Res. 1993 Dec 3;629(2):218-24.

209. Asashima T, Hori S, Ohtsuki S, Tachikawa M, Watanabe M, Mukai C, et al. ATP-binding cassette transporter G2 mediates the efflux of phototoxins on the luminal membrane of retinal capillary endothelial cells. Pharm Res. 2006 Jun;23(6):1235-42.

210. Tachikawa M, Toki H, Tomi M, Hosoya K. Gene expression profiles of ATP-binding cassette transporter A and C subfamilies in mouse retinal vascular endothelial cells. Microvascular research. 2008 Jan;75(1):68-72. 
Table 1 Expression of SLC transporters at the blood brain barrier

\begin{tabular}{|c|c|c|c|}
\hline transporter & mRNA expression & protein expression & cellular localization \\
\hline \multicolumn{4}{|l|}{ human } \\
\hline OATP1A2 & brain $[108,109]$ & brain [110] & $\begin{array}{l}\text { brain capillary endothelial } \\
\text { cells }[110]\end{array}$ \\
\hline OATP1C1 & brain [53] & & $\begin{array}{l}\text { brain capillary endothelial } \\
\text { cells [52] }\end{array}$ \\
\hline OATP2B1 & $\begin{array}{l}\text { brain microcapillaries } \\
\text { [32] }\end{array}$ & $\begin{array}{l}\text { brain microcapillaries } \\
\text { [111] }\end{array}$ & $\begin{array}{l}\text { brain capillary endothelial } \\
\text { cells [49] }\end{array}$ \\
\hline \multicolumn{4}{|l|}{ rat } \\
\hline rOATP1A4 & $\begin{array}{l}\text { brain [112], brain } \\
\text { microcapillaries [113] }\end{array}$ & brain [114] & $\begin{array}{l}\text { brain capillary endothelial } \\
\text { cells: luminal and } \\
\text { abluminal }[114]\end{array}$ \\
\hline rOATP1C1 & $\begin{array}{l}\text { brain microcapillaries } \\
{[115]}\end{array}$ & $\begin{array}{l}\text { Brain microcapillaires } \\
\text { [116] }\end{array}$ & $\begin{array}{l}\text { brain capillary endothelial } \\
\text { cells: luminal and } \\
\text { abluminal }[52,117]\end{array}$ \\
\hline rOATP2B1 & $\begin{array}{l}\text { brain [118], brain } \\
\text { microcapillaries [113] }\end{array}$ & & $\begin{array}{l}\text { brain capillary endothelial } \\
\text { cells: abluminal [113] }\end{array}$ \\
\hline \multicolumn{4}{|l|}{ mouse } \\
\hline mOATP1A1 & $\begin{array}{l}\text { brain microcapillaries } \\
\text { [119] }\end{array}$ & & \\
\hline mOATP1A4 & $\begin{array}{l}\text { brain microcapillaries } \\
{[119,120]}\end{array}$ & $\begin{array}{l}\text { brain microcapillaries } \\
{[87,116,121-125]}\end{array}$ & $\begin{array}{l}\text { brain capillary endothelial } \\
\text { cells: luminal and } \\
\text { abluminal [87] }\end{array}$ \\
\hline mOATP1A5 & $\begin{array}{l}\text { brain microcapillaries } \\
\text { [119] }\end{array}$ & & $\begin{array}{l}\text { brain capillary endothelial } \\
\text { cells [119] }\end{array}$ \\
\hline mOATP1A6 & $\begin{array}{l}\text { brain microcapillaries } \\
\text { [119] }\end{array}$ & & \\
\hline mOATP1C1 & $\begin{array}{l}\text { brain microcapillaries } \\
{[120,126,127]}\end{array}$ & $\begin{array}{l}\text { brain microcapillaries } \\
{[121,123-125]}\end{array}$ & $\begin{array}{l}\text { brain capillary endothelial } \\
\text { cells [52] }\end{array}$ \\
\hline
\end{tabular}




\begin{tabular}{|c|c|c|c|}
\hline mOATP2B1 & $\begin{array}{l}\text { brain microcapillaries } \\
{[120]}\end{array}$ & & \\
\hline \multicolumn{4}{|l|}{ human } \\
\hline OCT1 & brain [128] & $\begin{array}{l}\text { cultured brain } \\
\text { microvessel endothelial } \\
\text { cells: luminal [129] }\end{array}$ & $\begin{array}{l}\text { cultured brain microvessel } \\
\text { endothelial cells: luminal } \\
{[129]}\end{array}$ \\
\hline OCT2 & brain [130] & $\begin{array}{l}\text { cultured brain } \\
\text { microvessel endothelial } \\
\text { cells: luminal [129] }\end{array}$ & $\begin{array}{l}\text { cultured brain microvessel } \\
\text { endothelial cells: luminal } \\
{[129]}\end{array}$ \\
\hline OCT3 & $\begin{array}{l}\text { brain microcapillaries } \\
{[32,126]}\end{array}$ & $\begin{array}{l}\text { brain microcapillaries } \\
\text { [131] }\end{array}$ & $\begin{array}{l}\text { brain capillary endothelial } \\
\text { cells [131] }\end{array}$ \\
\hline OCTN2 & $\begin{array}{l}\text { brain microcapillaris } \\
{[32], \text { cultured brain }} \\
\text { microvessel } \\
\text { endothelial cells } \\
{[132]}\end{array}$ & & \\
\hline \multicolumn{4}{|l|}{ rat } \\
\hline rOCT1 & brain [133] & $\begin{array}{l}\text { cultured brain } \\
\text { microvessel endothelial } \\
\text { cells: luminal [129] }\end{array}$ & $\begin{array}{l}\text { cultured brain microvessel } \\
\text { endothelial cells: luminal } \\
{[129]}\end{array}$ \\
\hline rOCT2 & brain [133] & $\begin{array}{l}\text { cultured brain } \\
\text { microvessel endothelial } \\
\text { cells: luminal [129] }\end{array}$ & $\begin{array}{l}\text { cultured brain microvessel } \\
\text { endothelial cells: luminal } \\
{[129]}\end{array}$ \\
\hline \multicolumn{4}{|l|}{ mouse } \\
\hline mOCT1 & & & $\begin{array}{l}\text { cultured brain microvessel } \\
\text { endothelial cells: luminal } \\
{[129]}\end{array}$ \\
\hline mOCT2 & brain [134] & & $\begin{array}{l}\text { cultured brain microvessel } \\
\text { endothelial cells: luminal } \\
{[129]}\end{array}$ \\
\hline mOCT3 & $\begin{array}{l}\text { brain microcapillaries } \\
{[126]}\end{array}$ & & \\
\hline mOCTN2 & brain microcapillaries & & \\
\hline
\end{tabular}




\begin{tabular}{|c|c|c|c|}
\hline & [126] & & \\
\hline \multicolumn{4}{|l|}{ rat } \\
\hline rOAT2 & & $\begin{array}{l}\text { brain microcapillaries } \\
\text { [135] }\end{array}$ & \\
\hline rOAT3 & $\begin{array}{l}\text { brain microcapillaries } \\
{[136]}\end{array}$ & $\begin{array}{l}\text { brain microcapillaries } \\
{[123,125,135,137]}\end{array}$ & $\begin{array}{l}\text { brain microcapillaries: } \\
\text { luminal and abluminal } \\
{[138]}\end{array}$ \\
\hline \multicolumn{4}{|l|}{ mouse } \\
\hline mOAT2 & $\begin{array}{l}\text { brain microcapillaries } \\
{[126]}\end{array}$ & & \\
\hline mOAT3 & $\begin{array}{l}\text { brain microcapillaries } \\
{[120,126,136]}\end{array}$ & $\begin{array}{l}\text { brain microcapillaries } \\
{[121,124,137]}\end{array}$ & $\begin{array}{l}\text { brain microcapillaries: } \\
\text { abluminal [139] }\end{array}$ \\
\hline \multicolumn{4}{|l|}{ rat } \\
\hline rCNT2 & $\begin{array}{l}\text { brain microcapillaries } \\
{[140]}\end{array}$ & & \\
\hline \multicolumn{4}{|l|}{ human } \\
\hline ENT1 & & $\begin{array}{l}\text { brain } \\
\text { microcapillaries [32, 123, } \\
141]\end{array}$ & \\
\hline \multicolumn{4}{|l|}{ mouse } \\
\hline mENT1 & & $\begin{array}{l}\text { brain microcapillaries } \\
{[123,124]}\end{array}$ & \\
\hline \multicolumn{4}{|l|}{ human } \\
\hline MATE1 & $\begin{array}{l}\text { brain microcapillaries } \\
{[131]}\end{array}$ & $\begin{array}{l}\text { brain microcapillaries } \\
\text { [131] }\end{array}$ & $\begin{array}{l}\text { brain microcapillaires } \\
\text { [131] }\end{array}$ \\
\hline
\end{tabular}

Expression at the mRNA level was demonstrated by Northern blot analysis, PCR of isolated brain microcapillaries or by in situ hybridization. Protein expression was demonstrated by 
Western blotting or by proteomic methods using isolated brain microcapillaries. Cellular localization was demonstrated by immunohistochemistry and in some instances by domainspecific biotinylation experiments. 
Table 2 Expression of $\mathrm{ABC}$ transporters at the blood brain barrier

\begin{tabular}{|c|c|c|c|}
\hline transporter & mRNA expression & protein expression & cellular localization \\
\hline \multicolumn{4}{|l|}{ human } \\
\hline ABCG2(BCRP) & $\begin{array}{l}\text { brain microcapillaries } \\
{[142]}\end{array}$ & $\begin{array}{l}\text { brain microcapillaries } \\
{[32,123,141]}\end{array}$ & $\begin{array}{l}\text { brain microcapillaries: } \\
\text { luminal }[143,144]\end{array}$ \\
\hline MDR1 & $\begin{array}{l}\text { brain microcapillaries } \\
{[142]}\end{array}$ & $\begin{array}{l}\text { brain microcapillaries } \\
{[32,123]}\end{array}$ & $\begin{array}{l}\text { brain microcapillaries: } \\
\text { luminal [33] }\end{array}$ \\
\hline MRP1 & $\begin{array}{l}\text { brain microcapillaires } \\
{[142]}\end{array}$ & $\begin{array}{l}\text { brain microcapillaries } \\
{[141,145]}\end{array}$ & $\begin{array}{l}\text { brain microcapillaries: } \\
\text { luminal [146] }\end{array}$ \\
\hline MRP2 & brain [143] & & \\
\hline MRP3 & $\begin{array}{l}\text { brain microcapillaries } \\
{[142]}\end{array}$ & & \\
\hline MRP4 & $\begin{array}{l}\text { brain microcapillaries } \\
\text { [142] }\end{array}$ & $\begin{array}{l}\text { brain microcapillaries } \\
{[32,123,141]}\end{array}$ & $\begin{array}{l}\text { brain microcapillaries: } \\
\text { luminal [146] }\end{array}$ \\
\hline MRP5 & brain $[142,143]$ & & $\begin{array}{l}\text { brain microcapillaries, } \\
\text { luminal [146] }\end{array}$ \\
\hline MRP6 & $\begin{array}{l}\text { brain microcapillaries } \\
\text { [142] }\end{array}$ & & \\
\hline \multicolumn{4}{|l|}{ rat } \\
\hline rABCG2 & $\begin{array}{l}\text { brain microcapillaries } \\
{[142,147]}\end{array}$ & $\begin{array}{l}\text { brain microcapillaries } \\
{[116,137]}\end{array}$ & $\begin{array}{l}\text { brain microcapillaries: } \\
\text { luminal [147] }\end{array}$ \\
\hline rMDR1A & $\begin{array}{l}\text { brain } \\
\text { microcapillaries[113, } \\
142]\end{array}$ & $\begin{array}{l}\text { brain microcapillaries } \\
{[137]}\end{array}$ & $\begin{array}{l}\text { brain microcapillaries: } \\
\text { luminal }[145,148]\end{array}$ \\
\hline rMRP1 & $\begin{array}{l}\text { brain microcapillaries } \\
{[142,149]}\end{array}$ & $\begin{array}{l}\text { brain microcapillaries } \\
{[116]}\end{array}$ & $\begin{array}{l}\text { brain microcapillaries: } \\
\text { abluminal [113] }\end{array}$ \\
\hline rMRP2 & $\begin{array}{l}\text { brain microcapillaries } \\
{[150]}\end{array}$ & $\begin{array}{l}\text { brain microcapillaries } \\
\text { [151] }\end{array}$ & $\begin{array}{l}\text { brain microcapillaris: } \\
\text { luminal [150] }\end{array}$ \\
\hline rMRP3 & $\begin{array}{l}\text { brain microcapillaries } \\
\text { [152] }\end{array}$ & $\begin{array}{l}\text { brain microcapillaires } \\
\text { [116] }\end{array}$ & \\
\hline rMRP4 & $\begin{array}{l}\text { brain microcapillaires } \\
{[113,142]}\end{array}$ & $\begin{array}{l}\text { brain microcapillaries } \\
{[116,137]}\end{array}$ & $\begin{array}{l}\text { brain microcapillaries: } \\
\text { luminal }[113,153]\end{array}$ \\
\hline
\end{tabular}




\begin{tabular}{|c|c|c|c|}
\hline rMRP5 & $\begin{array}{l}\text { brain microcapillaries } \\
{[113,142]}\end{array}$ & $\begin{array}{l}\text { brain microcapillaries } \\
\text { [116] }\end{array}$ & $\begin{array}{l}\text { brain microcapillaries: } \\
\text { abluminal [113] }\end{array}$ \\
\hline rMRP6 & $\begin{array}{l}\text { brain microcapillaries } \\
{[142]}\end{array}$ & $\begin{array}{l}\text { brain microcapillaries } \\
{[116]}\end{array}$ & \\
\hline \multicolumn{4}{|l|}{ mouse } \\
\hline mABCG2 & $\begin{array}{l}\text { brain microcapillaries } \\
{[120,142,154][155]}\end{array}$ & $\begin{array}{l}\text { brain microcapillaries } \\
{[19,123-125,137]}\end{array}$ & $\begin{array}{l}\text { brain microcapillaries: } \\
\text { luminal [156] }\end{array}$ \\
\hline mMDR1A & $\begin{array}{l}\text { brain } \\
\text { microcapillaries[120, } \\
157]\end{array}$ & $\begin{array}{l}\text { brain microcapillaries } \\
{[19,121,124,125]}\end{array}$ & $\begin{array}{l}\text { brain microcapillaries: } \\
\text { luminal [18] }\end{array}$ \\
\hline mMRP1 & $\begin{array}{l}\text { brain microcapillaries } \\
{[142]}\end{array}$ & & $\begin{array}{l}\text { brain microcaplliaries: } \\
\text { abluminal [18] }\end{array}$ \\
\hline mMRP3 & $\begin{array}{l}\text { brain microcapillaires } \\
{[142]}\end{array}$ & $\begin{array}{l}\text { brain microcapillaries } \\
{[158]}\end{array}$ & \\
\hline mMRP4 & $\begin{array}{l}\text { brain microcapillaries } \\
{[120,142]}\end{array}$ & $\begin{array}{l}\text { brain microcapillaries } \\
{[19,121,123,125]}\end{array}$ & $\begin{array}{l}\text { brain microcapillaries: } \\
\text { luminal [153] }\end{array}$ \\
\hline mMRP5 & $\begin{array}{l}\text { brain microcapillaries } \\
{[142]}\end{array}$ & & $\begin{array}{l}\text { brain microcapillaries: } \\
\text { luminal [18] }\end{array}$ \\
\hline mMRP6 & $\begin{array}{l}\text { brain microcapillaries } \\
{[142]}\end{array}$ & & \\
\hline
\end{tabular}

Expression at the mRNA level was demonstrated by Northern blot analysis, PCR of isolated brain microcapillaries or by in situ hybridization. Protein expression was demonstrated by Western blotting or by proteomic methods using isolated brain microcapillaries. Cellular localization was demonstrated by immunohistochemistry and in some instances by domainspecific biotinylation experiments. 
Table 3 Expression of SLC transporters in choroid plexus

\begin{tabular}{|c|c|c|c|}
\hline transporter & mRNA expression & $\begin{array}{l}\text { protein } \\
\text { expression }\end{array}$ & cellular localization \\
\hline \multicolumn{4}{|l|}{ human } \\
\hline OATP1C1 & & & $\begin{array}{l}\text { choroid plexus epithelial } \\
\text { cells: apical and basolateral } \\
\text { [52] }\end{array}$ \\
\hline $\begin{array}{l}\text { OATP3A4 } \\
\text { (v1 andv2) }\end{array}$ & & & $\begin{array}{l}\text { choroid plexus epithelial } \\
\text { cells: basolateral [159] }\end{array}$ \\
\hline \multicolumn{4}{|l|}{ rat } \\
\hline rOATP1A1 & $\begin{array}{l}\text { choroid plexus [160, } \\
161]\end{array}$ & $\begin{array}{l}\text { choroid plexus } \\
{[160,161]}\end{array}$ & $\begin{array}{l}\text { choroid plexus epithelial } \\
\text { cells: apical [160] }\end{array}$ \\
\hline rOATP1A3 & choroid plexus [162] & $\begin{array}{l}\text { choroid plexus } \\
\text { [163] }\end{array}$ & $\begin{array}{l}\text { choroid plexus epithelial } \\
\text { cells: apical [162] }\end{array}$ \\
\hline rOATP1A4 & $\begin{array}{l}\text { choroid plexus [114, } \\
\text { 164-167] }\end{array}$ & & $\begin{array}{l}\text { choroid plexus epithelial } \\
\text { cells: basolateral [114] }\end{array}$ \\
\hline rOATP1A5 & $\begin{array}{l}\text { choroid plexus [161, } \\
165,167]\end{array}$ & $\begin{array}{l}\text { choroid plexus } \\
{[161,163]}\end{array}$ & $\begin{array}{l}\text { choroid plexus epithelial } \\
\text { cells: apical }[113,161]\end{array}$ \\
\hline rOATP1C1 & $\begin{array}{l}\text { choroid plexus }[163, \\
167,168]\end{array}$ & $\begin{array}{l}\text { choroid plexus } \\
\text { [117] }\end{array}$ & $\begin{array}{l}\text { choroid plexus epithelial } \\
\text { cells: basolateral and apical } \\
\text { [52] }\end{array}$ \\
\hline rOATP2A1 & $\begin{array}{l}\text { choroid plexus [168, } \\
169]\end{array}$ & & $\begin{array}{l}\text { crimary choroid epithelial } \\
\text { cells: apical [169]1 }\end{array}$ \\
\hline rOATP2B1 & choroid plexus [165] & & $\begin{array}{l}\text { choroid plexus epithelial } \\
\text { cells: apical [113] }\end{array}$ \\
\hline rOATP3A1 & choroid plexus [167] & & \\
\hline rOATP4A1 & choroid plexus [165] & & \\
\hline \multicolumn{4}{|l|}{ mouse } \\
\hline mOATP1A4 & choroid plexus [119] & $\begin{array}{l}\text { choroid plexus } \\
\text { [87] }\end{array}$ & \\
\hline mOATP1A5 & choroid plexus [119] & choroid plexus & choroid plexus epithelial \\
\hline
\end{tabular}




\begin{tabular}{|c|c|c|c|}
\hline & & [119] & cells: apical[119] \\
\hline mOATP1A6 & choroid plexus [119] & & \\
\hline mOATP1C1 & $\begin{array}{l}\text { choroid plexus [127, } \\
170]\end{array}$ & $\begin{array}{l}\text { choroid plexus } \\
\text { [171] }\end{array}$ & $\begin{array}{l}\text { choroid plexus epithelial } \\
\text { cells: basolateral [171], apical } \\
\text { and basolateral [52] }\end{array}$ \\
\hline \multicolumn{4}{|l|}{ rat } \\
\hline rOCT1 & choroid plexus [165] & & \\
\hline rOCT2 & $\begin{array}{l}\text { choroid plexus[168, } \\
172]\end{array}$ & & \\
\hline rOCT3 & $\begin{array}{l}\text { choroid plexus [165, } \\
172]\end{array}$ & & $\begin{array}{l}\text { choroid plexus epithelial cells } \\
\text { [173] }\end{array}$ \\
\hline rOCTN1 & choroid plexus [165] & & \\
\hline rOCTN2 & $\begin{array}{l}\text { choroid plexus [165, } \\
167]\end{array}$ & & \\
\hline \multicolumn{4}{|l|}{ mouse } \\
\hline mOCTN1 & & & $\begin{array}{l}\text { choroid plexus epithelial cells } \\
{[174]}\end{array}$ \\
\hline mOCTN2 & & & $\begin{array}{l}\text { choroid plexus epithelial cells } \\
{[174]}\end{array}$ \\
\hline mOCTN3 & & & $\begin{array}{l}\text { choroid plexus epithelial cells } \\
\text { [174] }\end{array}$ \\
\hline \multicolumn{4}{|l|}{ human } \\
\hline OAT1 & & & $\begin{array}{l}\text { choroid plexus epithelial cells } \\
\text { [175] }\end{array}$ \\
\hline OAT3 & & & $\begin{array}{l}\text { choroid plexus epithelial } \\
\text { cells[175] }\end{array}$ \\
\hline \multicolumn{4}{|l|}{ rat } \\
\hline rOAT1 & $\begin{array}{l}\text { choroid plexus }[95,167, \\
168]\end{array}$ & & \\
\hline rOAT2 & choroid plexus $[95,165$, & & \\
\hline
\end{tabular}




\begin{tabular}{|c|c|c|c|}
\hline & 168] & & \\
\hline rOAT3 & $\begin{array}{l}\text { choroid plexus [165, } \\
167]\end{array}$ & $\begin{array}{l}\text { choroid plexus } \\
{[176]}\end{array}$ & $\begin{array}{l}\text { choroid plexus epithelial } \\
\text { cells: apical }[113,176]\end{array}$ \\
\hline \multicolumn{4}{|l|}{ mouse } \\
\hline mOAT1 & $\begin{array}{l}\text { choroid plexus }[3,95 \text {, } \\
177]\end{array}$ & & \\
\hline mOAT2 & choroid plexus [95] & & \\
\hline mOAT3 & choroid plexus $[3,177]$ & & \\
\hline \multicolumn{4}{|l|}{ rat } \\
\hline rCNT2 & $\begin{array}{l}\text { choroid plexus } \\
{[165] \text { Primary choroid }} \\
\text { plexus epithelial cells } \\
{[167,178]}\end{array}$ & $\begin{array}{l}\text { primary choroid } \\
\text { plexus epithelial } \\
\text { cells }[178]\end{array}$ & \\
\hline rCNT3 & $\begin{array}{l}\text { choroid plexus } \\
{[165] \text { Primary choroid }} \\
\text { plexus epithelial cells } \\
{[167,168,178]}\end{array}$ & & \\
\hline \multicolumn{4}{|l|}{ human } \\
\hline ENT1 & & $\begin{array}{l}\text { choroid plexus } \\
{[179]}\end{array}$ & \\
\hline ENT2 & & $\begin{array}{l}\text { choroid plexus } \\
{[179]}\end{array}$ & \\
\hline ENT3 & & $\begin{array}{l}\text { choroid plexus } \\
{[179]}\end{array}$ & \\
\hline \multicolumn{4}{|l|}{ human } \\
\hline CNT3 & & $\begin{array}{l}\text { choroid plexus } \\
{[179]}\end{array}$ & \\
\hline rat & & & \\
\hline
\end{tabular}




\begin{tabular}{|c|c|c|c|}
\hline rENT1 & $\begin{array}{l}\text { choroid plexus }[165], \\
\text { choroid plexus epithelial } \\
\text { cells }[167,180]\end{array}$ & $\begin{array}{l}\text { primary choroid } \\
\text { plexus epithelial } \\
\text { cells [178] }\end{array}$ & \\
\hline rENT2 & $\begin{array}{l}\text { choroid plexus [165, } \\
181] \text { Primary choroid } \\
\text { plexus epithelial cells } \\
{[167,178]}\end{array}$ & $\begin{array}{l}\text { primary choroid } \\
\text { plexus epithelial } \\
\text { cells [178] }\end{array}$ & \\
\hline rPEPT1 & choroid plexus [165] & & \\
\hline rPEPT2 & $\begin{array}{l}\text { choroid plexus }[165, \\
167,168,182]\end{array}$ & $\begin{array}{l}\text { choroid plexus } \\
{[163,183]}\end{array}$ & $\begin{array}{l}\text { choroid plexus epithelial } \\
\text { cells: apical [184], crimary } \\
\text { choroid plexus epithelial } \\
\text { cells: apical \{Shu, } 2002 \\
\# 8387\end{array}$ \\
\hline mouse & & & \\
\hline mENT1 & & $\begin{array}{l}\text { choroid } \\
\text { plexus[123, 124] }\end{array}$ & \\
\hline
\end{tabular}

Expression at the mRNA level was demonstrated by Northern blot analysis, PCR of isolated choroid plexus or by in situ hybridization. Protein expression was demonstrated by Western blotting or by proteomic methods using isolated choroid. Cellular localization was demonstrated by immunohistochemistry. 
Table 4 Expression of $\mathrm{ABC}$ transporters in choroid plexus

\begin{tabular}{|c|c|c|c|}
\hline transporter & mRNA expression & protein expression & cellular localization \\
\hline \multicolumn{4}{|l|}{ human } \\
\hline MDR1 & $\begin{array}{l}\text { choroid plexus } \\
\text { [185] }\end{array}$ & $\begin{array}{l}\text { choroid plexus }[145, \\
186]\end{array}$ & $\begin{array}{l}\text { choroid plexus epithelial cells } \\
{[144,186]}\end{array}$ \\
\hline MRP1 & $\begin{array}{l}\text { choroid Niehof, } \\
2009 \# 8433\}\end{array}$ & $\begin{array}{l}\text { choroid plexus [145, } \\
186]\end{array}$ & $\begin{array}{l}\text { choroid plexus epithelial cells } \\
{[144,186]}\end{array}$ \\
\hline MRP2 & $\begin{array}{l}\text { choroid plexus } \\
\text { [185] }\end{array}$ & & \\
\hline MRP3 & $\begin{array}{l}\text { choroid plexus } \\
\text { [185] }\end{array}$ & & \\
\hline MRP4 & $\begin{array}{l}\text { choroid plexus } \\
\text { [185] }\end{array}$ & & $\begin{array}{l}\text { choroid plexus epithelial cells: } \\
\text { basolateral [153] }\end{array}$ \\
\hline MRP5 & $\begin{array}{l}\text { choroid plexus } \\
\text { [185] }\end{array}$ & & \\
\hline MRP6 & $\begin{array}{l}\text { choroid plexus } \\
\text { [185] }\end{array}$ & & \\
\hline \multicolumn{4}{|l|}{ rat } \\
\hline rABCG2 & $\begin{array}{l}\text { choroid plexus } \\
{[187,188]}\end{array}$ & choroid plexus [188] & \\
\hline rMDR1A & $\begin{array}{l}\text { choroid plexus } \\
{[165,188]}\end{array}$ & $\begin{array}{l}\text { choroid plexus [145, } \\
\text { 186] (C219) [188] }\end{array}$ & $\begin{array}{l}\text { choroid plexus epithelial cells } \\
{[186](\mathrm{C} 219)}\end{array}$ \\
\hline rMDR1B & $\begin{array}{l}\text { choroid plexus } \\
{[165,167]}\end{array}$ & $\begin{array}{l}\text { choroid plexus [145, } \\
\text { 186] (C219) }\end{array}$ & $\begin{array}{l}\text { choroid plexus epithelial cells } \\
{[186](\mathrm{C} 219)}\end{array}$ \\
\hline rMRP1 & $\begin{array}{l}\text { choroid plexus } \\
{[165-167,187,188]}\end{array}$ & $\begin{array}{l}\text { choroid plexus }[145, \\
186,189]\end{array}$ & $\begin{array}{l}\text { choroid plexus epithelial cells: } \\
\text { basolateral }[18,113,119,145 \text {, } \\
\text { 190] }\end{array}$ \\
\hline rMRP2 & $\begin{array}{l}\text { choroid plexus } \\
{[165,168,191]}\end{array}$ & & \\
\hline rMRP3 & $\begin{array}{l}\text { choroid plexus } \\
\text { [165] }\end{array}$ & & \\
\hline rMRP4 & choroid plexus & choroid plexus [163, & choroid plexus epithelial cells: \\
\hline
\end{tabular}




\begin{tabular}{|c|c|c|c|}
\hline & {$[165,167,191]$} & 187] & basolateral $[113,153]$ \\
\hline rMRP5 & $\begin{array}{l}\text { choroid plexus } \\
{[165,167,191]}\end{array}$ & & \\
\hline rMRP6 & $\begin{array}{l}\text { choroid plexus } \\
\text { [165] }\end{array}$ & choroid plexus [163] & \\
\hline mouse & & & \\
\hline mABCG2 & choroid plexus [3] & choroid plexus [192] & $\begin{array}{l}\text { choroid plexus epithelial cells: } \\
\text { apical [156] }\end{array}$ \\
\hline mMDR1A & choroid plexus[3] & & \\
\hline mMRP1 & choroid plexus [3] & & $\begin{array}{l}\text { choroid plexus epithelial cells: } \\
\text { [193], basolateral [190] }\end{array}$ \\
\hline mMRP4 & $\begin{array}{l}\text { choroid plexus }[3, \\
170]\end{array}$ & choroid plexus [153] & $\begin{array}{l}\text { choroid plexus epithelial cells: } \\
\text { basolateral }[52,153]\end{array}$ \\
\hline
\end{tabular}

Expression at the mRNA level was demonstrated by Northern blot analysis, PCR of isolated choroid plexus or by in situ hybridization. Protein expression was demonstrated by Western blotting or by proteomic methods using isolated choroid plexus. Cellular localization was demonstrated by immunohistochemistry. 
Table 5 Transporter expression in blood retinal barriers

\begin{tabular}{|c|c|c|c|}
\hline transporter & mRNA expression & protein expression & cellular localization \\
\hline \multicolumn{4}{|l|}{ human } \\
\hline OATP1A2 & retina [82] & retina [49] & $\begin{array}{l}\text { retinal pigmented epithelial } \\
\text { cells [82] }\end{array}$ \\
\hline OATP1B3 & retina [194] & & \\
\hline OATP1C1 & & & $\begin{array}{l}\text { Choroid plexus epithelial } \\
\text { cells: apical and basolateral } \\
\text { [52] }\end{array}$ \\
\hline OATP2B1 & retina $[82]$ & retina [49] & $\begin{array}{l}\text { retinal pigmented epithelial } \\
\text { cells [82] }\end{array}$ \\
\hline \multicolumn{4}{|l|}{ rat } \\
\hline rOATP1A4 & $\begin{array}{l}\text { retina }[164,195] \text {, retinal } \\
\text { pigmented epithelial } \\
\text { cells [196], blood retinal } \\
\text { capillaries [197] }\end{array}$ & retina $[196,198]$ & $\begin{array}{l}\text { blood retinal capillary } \\
\text { endothelial cells: abluminal } \\
\text { [198], retinal pigmented } \\
\text { epithelial cells, apical [196, } \\
\text { 198, 199] }\end{array}$ \\
\hline rOATP1A5 & retina $[164,196,200]$ & retina [196] & $\begin{array}{l}\text { retinal pigmented epithelial } \\
\text { cells [201] }\end{array}$ \\
\hline rOATP1C1 & $\begin{array}{l}\text { blood retinal capillaries } \\
\text { [197] }\end{array}$ & retina [198] & $\begin{array}{l}\text { blood retinal capillary cells: } \\
\text { luminal and abluminal [198], } \\
\text { retinal pigmented epithelial } \\
\text { cells, basolateral [198] }\end{array}$ \\
\hline rOATP2B1 & retina $[195]$ & & \\
\hline rOATP3A1 & retina $[195]$ & & \\
\hline rOATP4A1 & retina $[195,201]$ & retina [201] & \\
\hline \multicolumn{4}{|l|}{ human } \\
\hline OCT1 & & $\begin{array}{l}\text { retinal pigmented } \\
\text { epithelium [202] }\end{array}$ & \\
\hline OCT2 & retina [194] & & \\
\hline
\end{tabular}




\begin{tabular}{|c|c|c|c|}
\hline OCT3 & retina [194] & & \\
\hline OCTN2 & retina [194] & & \\
\hline \multicolumn{4}{|l|}{ rat } \\
\hline rOCT1 & retina $[195]\{$ & & \\
\hline rOCT2 & retina $[195]\{$ & & \\
\hline \multicolumn{4}{|l|}{ mouse } \\
\hline mOCT3 & $\begin{array}{l}\text { retinal pigmented } \\
\text { epithelial cells [203] }\end{array}$ & & \\
\hline mOCTN1 & $\begin{array}{l}\text { blood retinal capillary } \\
\text { epithelial cells [204] }\end{array}$ & & \\
\hline mOCTN2 & $\begin{array}{l}\text { blood retinal capillary } \\
\text { epithelial cells [204] }\end{array}$ & & \\
\hline \multicolumn{4}{|l|}{ rat } \\
\hline rOAT2 & retina [195] & & \\
\hline rOAT3 & $\begin{array}{l}\text { retina }[195], \text { Blood } \\
\text { retinal capillaries [205] }\end{array}$ & $\begin{array}{l}\text { primary cultured } \\
\text { blood retinal } \\
\text { capillary } \\
\text { endothelial cells } \\
\text { [205] }\end{array}$ & $\begin{array}{l}\text { blood retinal capillary } \\
\text { endothelial cells: abluminal } \\
\text { [205] }\end{array}$ \\
\hline \multicolumn{4}{|l|}{ rat } \\
\hline rCNT2 & retina [195] & & \\
\hline rCNT3 & retina [195] & & \\
\hline \multicolumn{4}{|l|}{ human } \\
\hline PEPT1 & & $\begin{array}{l}\text { retinal pigmented } \\
\text { epithelium [202] }\end{array}$ & \\
\hline PEPT2 & & $\begin{array}{l}\text { retinal pigmented } \\
\text { epithelium [202] }\end{array}$ & \\
\hline rat & & & \\
\hline
\end{tabular}




\begin{tabular}{|c|c|c|c|}
\hline rENT1 & retina [195] & & \\
\hline rENT2 & retina [195] & & \\
\hline \multicolumn{4}{|l|}{ human } \\
\hline $\mathrm{ABCG} 2$ & retina [194] & & \\
\hline MDR1 & $\begin{array}{l}\text { retina [194,] primary } \\
\text { cultured retinal } \\
\text { pigmented epithelial } \\
\text { cells [206] }\end{array}$ & $\begin{array}{l}\text { primary cultured } \\
\text { retinal pigmented } \\
\text { epithelial cells } \\
\text { [206] }\end{array}$ & $\begin{array}{l}\text { retinal pigmented epithelial } \\
\text { cells:apical and basolateral } \\
\text { [206] }\end{array}$ \\
\hline MRP1 & $\begin{array}{l}\text { retina [194], primary } \\
\text { cultured retinal } \\
\text { pigmented epithelial } \\
\text { cells[207] }\end{array}$ & $\begin{array}{l}\text { primary cultured } \\
\text { retinal pigmented } \\
\text { epithelial cells } \\
\text { [207] }\end{array}$ & \\
\hline MRP5 & retina [194] & & \\
\hline \multicolumn{4}{|l|}{ rat } \\
\hline rABCG2 & retina [195] & & \\
\hline rMDR1 & $\begin{array}{l}\text { blood retinal capillaries } \\
\text { [197], retina [195] }\end{array}$ & & $\begin{array}{l}\text { blood retinal capillary } \\
\text { endothelial cells: [208], } \\
\text { luminal [205] } \\
\text { retinal pigmented epithelial } \\
\text { cells [208] }\end{array}$ \\
\hline rMRP1 & retina [195] & & \\
\hline rMRP2 & retina [195] & & \\
\hline rMRP3 & retina [195] & & \\
\hline rMRP4 & retina [195] & & \\
\hline rMRP5 & retina [195] & & \\
\hline rMRP6 & retina [195] & & \\
\hline \multicolumn{4}{|l|}{ mouse } \\
\hline mABCG2 & retina [209] & retina [209] & $\begin{array}{l}\text { blood retinal capillary } \\
\text { endothelial cells: luminal } \\
{[209]}\end{array}$ \\
\hline
\end{tabular}




\begin{tabular}{|l|l|l|l|}
\hline mMRP1 & $\begin{array}{l}\text { blood retinal capillaries } \\
{[210]}\end{array}$ & & \\
\hline mMRP3 & $\begin{array}{l}\text { blood retinal capillaries } \\
{[210]}\end{array}$ & & \\
\hline mMRP4 & $\begin{array}{l}\text { blood retinal capillaries } \\
{[210]}\end{array}$ & & \\
\hline mMRP6 & $\begin{array}{l}\text { blood retinal capillaries } \\
{[210]}\end{array}$ & & \\
\hline
\end{tabular}

Expression at the mRNA level was demonstrated by PCR of isolated retinal microcapillaries. Protein expression was demonstrated by Western blotting using isolated retinal microcapillaries and cellular localization was demonstrated by immunohistochemistry. 